\title{
Intuition and Insight: two concepts that illuminate the tacit in science education
}

We can know more than we can tell.

(Polanyi, 1966/2009, p4)

\subsection{Introduction: Studying the tacit}

Tacit knowledge may seem a paradoxical and unrewarding area for study. Tacit knowledge is defined as knowledge that 'cannot be explicitly stated' (Polanyi, 1966, p4, italics removed), so it must seem that any investigation of implicit knowledge, must remain, to some extent, speculative. We tend to overvalue the effectiveness of introspection (Pronin, 2009, p3) and assume we are fully aware of our own thinking (Lewicki, Hill, \& Czyzewska, 1992, p797). However, much of higher-order processing may not be available to conscious awareness (Nisbett \& Wilson, 1977, p232).

Researchers have sought to understand nonconscious perception by its influence on conscious thought (Dresp-Langely, 2012, p3) but, by definition, can only be aware of the effects of the nonconscious processes not the tacit processes themselves (Miller, 1962, p50). This indirect awareness distorts the perception of tacit processes, for example, in the case of insight, giving the appearance of rapid, almost spontaneous arrival of ideas into conscious awareness (Smith, 1995, p242). The inaccessibility of tacit knowledge might encourage researchers to avoid the concept entirely.

However, a number of researchers have developed experimental approaches that have allowed them to make assumptions about tacit knowledge (Wagner \& Sternberg, 1985; Reber, 1989; Kanheman, 2011). Though tacit knowledge cannot be studied directly, its influence on conscious thought may be inferred. To draw an analogy, physicists cannot observe black holes directly, but study their properties through their interactions with surrounding matter (Chow, 2008, p101). Two processes by which tacit knowledge interacts with conscious thinking are intuition and insight. Though insight and intuition have a history of being used synonymously (Simon, 1986, p242; Fischbein, 1987, p5; Schooler \& Dougal, 1999, p281), I will argue that they are two distinct phenomena. The terms intuition and insight will be defined in more detail below but a brief definition will be given here to aid the reader. Intuitions may be thought of as tacit hunches or feelings that come to mind with little conscious awareness of processing. An insight is an explicit awareness of novel relations that arrives with apparent suddenness but with little conscious awareness of processing. It is important to draw an ontological distinction between hypothetical cognitive entities (hunches, feelings, awarenesses) and processes that make use of those entities (See table 1). This paper will make use of both senses of the terms.

\begin{tabular}{|l|l|l|}
\hline & $\begin{array}{l}\text { As a supposed cognitive entity } \\
\text { (E.g. an intuition, an insight) }\end{array}$ & $\begin{array}{l}\text { As a process (E.g. intuitive thinking/ to } \\
\text { have an insight) }\end{array}$ \\
\hline Intuition & $\begin{array}{l}\text { An intuition is a tacit hunch or } \\
\text { feeling that influences thought } \\
\text { with little conscious effort. }\end{array}$ & $\begin{array}{l}\text { The influence of tacit hunches or } \\
\text { feelings on conscious thought. }\end{array}$ \\
\hline Insight & $\begin{array}{l}\text { An insight is an explicit } \\
\text { awareness of novel relations } \\
\text { between concepts that arrives } \\
\text { with apparent suddenness and } \\
\text { little conscious awareness of } \\
\text { processing. }\end{array}$ & $\begin{array}{l}\text { The development of an explicit } \\
\text { awareness of novel relations between } \\
\text { concepts with apparent suddenness } \\
\text { and little conscious awareness of } \\
\text { processing. }\end{array}$ \\
\hline
\end{tabular}


Table 1: Defining intuition and insight as entities and processes

These definitions highlight distinctions between insight and intuition. Insights, as experienced, typically have a short duration, though an extended period of conscious and tacit incubation may have preceded the insight. Secondly, given its description as an awareness of novel relations, insight usually occurs only once for a given set of relations (it is possible that forgetting an insight may allow a similar event to reoccur, though this is not seen as the norm). Typically the novel awareness developed in insight becomes part of explicit understanding. By contrast, intuitions may influence conscious thought repeatedly over an extended period. It is also worth noting the different availability to consciousness of the two processes: an insight is a conscious awareness (though the processes that lead to this result are, at least partly, tacit) whereas intuitions themselves may be imagined as tacit knowledge.

Both intuition and insight can be conceptualised as processes in which the tacit interacts with conscious thought (see figure 1). The tacit-explicit connection, which exists in both concepts, makes them a fruitful place to begin the study of the nonconscious. Using the concepts of intuition and insight as links to the non-conscious, this article will examine how tacit knowledge and processes may be relevant to science education.

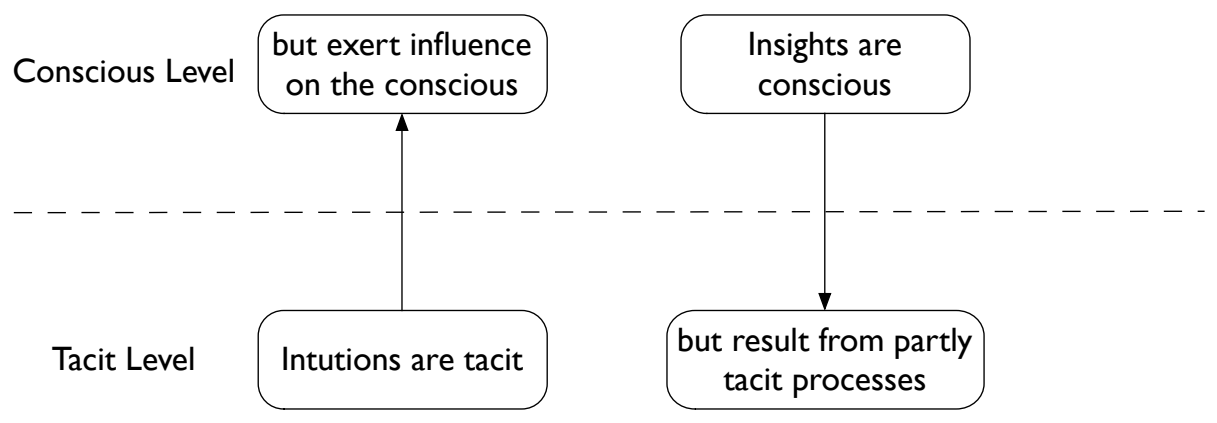

Figure 1: Intuition and insight as links to the tacit

I will begin section two by defining and differentiating the terms intuition and insight and explaining their relation to tacit knowledge. The paper is then divided into two sections, separately examining the concepts of intuition and insight. In discussing each concept I shall address the following themes: 1) the concept in the work of scientists; 2) the relationship of the concept to constructs in science education research; 3 ) the conditions that promote or hinder the use of the concept; 4) the productiveness of the concept; and 5) proposed strategies to support the productive form of the concept in the classroom. The differing nature of the two concepts requires that, in section two, the constructs in science education, the sections on intuition and insight will have differing foci. For intuition, I will examine two conceptualisations of intuition: embodied cognition and abstracted rules. This will lead to a discussion of the entanglement of tacit and explicit concepts. In the insight section, I will discuss the relationship between insight and rapid conceptual change and the formation of novel conceptual connections. The review concludes with the proposal of five research questions to guide a future research programme into tacit knowledge in science education. 


\subsection{Defining terms}

\subsection{Definitions of intuition}

In the recent years, a growing interest in the previously neglected phenomenon of intuition (Claxton, 1988, p217) has seen the publication of several popular books on the subject (Chabris \& Simons, 2010; Gladwell, 2005; Myers, 2004). Indeed, empirical research-programs investigating intuition exist in the fields of nursing, emergency medicine, business and law among others (Sinclair, 2011). Hodgkinson and SaddlerSmith (2011, p52) argue that intuition is 'a legitimate subject of social scientific inquiry with important implications for educational... decision-making' and present multiple empirical methods that have been used to investigate the construct in the laboratory (for detail on the methods used to study intuition see: Sinclair, 2014 and Glöckner \& Witteman, 2010).

The term intuition derives from the Latin intueri meaning 'to look upon' or 'to see within' (Goldberg, 1985, p31). Intuition has been described as a 'semantic riddle' (Bastick, 1982, p1) and 'the last frontier of the mind' (Cloninger, 2006, p15) as it was thought to be resistant to empirical measurement (Sinclair \& Ashkansay, 2005, p355). Petitmengin-Peugeot (1999, p44) argues the commonly reported difficulty in defining intuition arises from its nonconscious nature. Definitions of intuition (for a comprehensive list see: Dane \& Pratt, 2007, p35) tend to share two characteristics: a) intuition is rapid and b) it occurs without conscious awareness. Of the seventeen definitions of intuition listed by Dane and Pratt (2007, p35) eleven include some sense of nonconscious processing and five refer to its speed. For example Kahneman (2003, p697) defines intuition as 'thoughts and preferences that come to mind quickly and without much reflection' and Lieberman (2000, p111) opts for '[t]he subjective experience of a mostly nonconscious process- fast, a-logical, and inaccessible to consciousness.' In choosing the major components of intuition, Dane and Pratt (2007, p36) propose, in addition to speed and nonconsciousness, a holistic and an affective nature, which I will argue, are unnecessary elements for a definition of intuition in science education. The description of holistic understanding as the 'recognition of patterns and structures' (Dane \& Pratt, 2007, p37), is closer to the definition of insight given above, than to intuition. Physical intuitions may exist as tacit hunches or feelings concerning physical systems; for example, a moving object requires a force to remain in motion (Driver et al., 1994, p158). A holistic component of intuition is not always present. Dane and Pratt's (2007, p36) final component of intuition, affect, is difficult to define but may be thought of as 'consciously accessible feelings' (Fredrickson, 2001, p2), including emotions but also physical sensations and moods. By definition, intuitions are nonconscious and though emotions may, sometimes, be associated with fruitful applications of intuitions, there is no evidence to suggest that such feelings occur in all cases. Though I will argue that kinesthetic representations may be a component of some intuitions (see section 3.2.1), there is insufficient evidence to claim intuitions are invariably grounded in physical sensations. Therefore, I shall restrict my analysis to the two necessary components of intuition: its speed and nonconscious nature.

\subsubsection{Speed of intuition}

Many definitions of intuition contain some implication of rapidity (E.g. 'fast' (Lieberman, 2000, p111); 'immediate knowledge' (Myres, 2002, p129); 'operates...quickly' (Kahneman, 2011, p105)). In discussing the nature of intuitive physics, diSessa (2002, p39) describes the activation of phenomenological knowledge as having a rapidity of recognition that cannot be put into words: 'One simply sees them in 
some situations and not in others.' It may be that non-formal (or intuitive) concepts 'can be interpreted in ways which are fast and effortless' as they require 'little or no deliberate processing, nor any explicit invocation of a definition of the concept' (Reif, 1987, p403). Whilst intuition is commonly described as rapid, slower tacit realisation are also reported:

However, neither speed nor certainty are necessarily correlates of intuitive thought. While it is true that we often make speedy judgments about many issues, some people report experiencing intuition as a slow realization of a state, an impression being built up over time by a succession of minor intuitions. (Hogarth, 2001, p10)

The experienced speed of intuition may be due to a lack of awareness of underlying processing (Bolte \& Goschke, 2005, p1249) and 'reflect the sudden conscious availability' of a tacit concept (Kounios, et al., 2006, p883) rather than the existence of some special, rapid, form of cognition. It is problematic that a defining feature of intuition, it's apparent rapid availability, may simply be a correlate of its nonconscious nature and not a reflection of speed of processing. However, the subjective experience of rapidity of occurrence to consciousness is a useful marker for describing the intuitive process.

\subsubsection{Nonconscious nature of intuition}

At least some of what goes on in the brain is not conscious and not available to conscious thought (Nisbett \& Wilson, 1977). Intuitions are seen as arising from such tacit knowledge (Wyatt, 2001; Smith, 2001) that may develop through the operation of implicit learning, a nonconscious process that results in abstracted knowledge (Reber, 1989, p219). Evidence from a number of studies indicates participants may learn to perform well on a task but be unable to describe explicitly the skills they have used (Reber, 1989; Berry \& Broadbent, 1988; Miller, 1967). One construct that accounts for tacit knowledge is diSessa's phenomenological primitives or p-prims: "pieces" of intuitive knowledge' (diSessa, 2000, p91). DiSessa describes p-prims as 'inarticulate,' 'not strongly related to dictionary lexicon' and without 'explicit propositional form' (diSessa, 1993, p119). P-prims are thought to be abstracted from 'body sensations and internal sensorimotor terms' (diSessa, 1993, p119) and therefore beyond language. The most developed account of intuition in the science education literature occurs in Clement's (2008) work. As I have argued in table one, Clement (2008, p207) proposed intuition can be used to refer to both 'knowledge structures and nonformal reasoning processes.' He implies that the lack of conscious justification of intuitions may due to their axiomatic nature:

An intuition is a knowledge structure (schema) that resides in longterm memory and that can be activated to provide an interpretation of or an expectation about a system...Subjects do not feel a need to further justify, derive, or explain intuitions. They are self-evident. This does not mean that an explanation or finer analysis is impossible, but that none is needed because the behavior is self-evident to the subject. (Clement, 2008, p208)

Kahneman (2011, pp. 98-99) describes such nonformal reasoning processes as heuristics. Heuristics are categorised as belonging to a scheme of thought called system 1 , involving automatic, rapid and tacit cognition. System 1 processes may be overridden by the slower, more deliberate and explicit system 2 . The interaction between these two kinds of processing determines how we come to understand the world: a model known 
as the 'two systems model' (Kahneman, 2011, pp. 98-99). One example of a system 1 process is the availability heuristic: the tendency to overestimate the likelihood of events with greater "availability" in memory, for example the propensity to overestimate the likelihood of emotionally charged events such as plane crashes (Kahneman, 2011, p98, pp. 129-145). Heuristics can be powerful shortcuts in some situations but lead to incorrect assumptions in other contexts (see section 3.4). The experience of intuition, an explicit feeling of knowledge that is not full articulable, bridges the boundary between the tacit and explicit.

\subsection{Definitions of insight}

Everyone who has ever communicated something complicated to another person has seen it. It is a troubled expression framed with quizzical eyebrows. As the teacher, the face you are looking into is clearly providing nonverbal cues that your eloquent explanation is not having its intended results and the learner is not learning. Then, sometimes almost magically, sometimes after considerable effort, sometimes after intervention from others, the facial muscles on the learner relax, and you can literally "see" the learner crossing to the other side. Something new is now understood. Mission accomplished. You really are a teacher-at least for this moment. (Halpern, 2005, p141)

Although it is related to, and often confused with intuition, insight is the more clearly defined process (Hogarth, 2001, p12). Insight has been described as 'the process by which a problem solver suddenly moves from a state of not knowing how to solve a problem to a state of knowing how to solve it' (Mayer, 1995, p3), and is linked with "Aha!" experiences (Kounios \& Beeman, 2009; Dominowski \& Dallob, 1995, p38). Confining insight to the domain of problem solving would seem to limit its scope; it might be assumed that students can experience moments of insight in learning about a new conceptual area as well as in problem solving.

A broader definition of insight conceptualises it as the movement from relative confusion to comprehension (Dominowski \& Dallob, 1995, p37). This is useful as an approximation but problematic as comprehension is both difficult to define and assess. Probably the most common component of definitions of insight is the process of forming novel connections between concepts (see for example: Wren et al., 2004, p390; Bowden et al., 2005, p324; Jung-Beeman et al., 2004, p506). Consider one of the most cited models of insight: Sternberg and Davidson's three-process model $(1983, \mathrm{p} 53)$. This construction proposes three possible routes to insight: a) selective encoding: 'sifting out relevant information'; b) selective combination: 'combining what might originally seem to be isolated pieces of information into a unified whole'; and c) selective comparison 'relating newly acquired information to information acquired in the past' (Sternberg \& Davidson, 1983, pp. 53-54).

The selective encoding process (Sternberg \& Davidson, 1983, p53), which is likely to involve the kind of extended memory searches reported before insight (JungBeeman et al., 2004, p504), may occur during the incubation period that precedes insight (see section 3.3). As the tacit nature of these processes makes them challenging to describe (though neural-imaging studies are beginning to provide some information (Jung-Beeman et al., 2004)), the definition of insight used in this paper will focus on the sudden conscious awareness of novel relations between concepts. 
As with intuition, the most significant investigation of the concept in science education is found in John Clement's research. He argues sudden advances in learning are insight-like if:

1. The breakthrough is an important idea...

2 . The breakthrough adds significantly to the subject's knowledge. It produces a large structural change in the subject's model...

3. The subject's ideas are generated fairly quickly during the breakthrough, and he achieves rapid subsequent progress towards a solution.

4. The breakthrough is accompanied by more complex phenomena:

(a) It is accompanied by indicators of emotional response -

surprise, joy, satisfaction.

(b) The subject realizes immediately that something

important has been discovered. (Clement, 2008, p103)

In addition to insight events, Clement proposes 'pure Eureka events,' insights in which the emergence of the new idea is 'extremely fast,' an existing idea is replaced in its entirety by a new model and the 'the process is not explainable via normal reasoning processes; extraordinary thought processes that are unconscious or different from normal thought processes are involved' (Clement, 2008, pp. 103-104). It seems unlikely that these two processes are clearly distinguishable, and no evidence is presented for 'extraordinary thought processes' yet the definition captures something of the essence of a moment of insight. It would seem that points (1) and (4) of Clement's definition of insight above may be occasional, but by no means necessary, correlates of insight. Researchers report the unreliability of emotional markers of understanding (Ylikoski, 2009, p104) and I do not feel sufficient evidence exists to link all moments of insight with such feelings. In addition, it is difficult to understand what 'important' might mean in this context.

In section 4.2.2, I will propose examples of insight as existing at a range of complexities: some insights involve the formation of relatively simple connections whereas others involve the widespread rearrangements of conceptual structure. The meaning of a concept is defined by its relationship to other concepts (Taber, 2013, p232), and hence changes in conceptual connections can be seen as conceptual change (Tyson et al., 1997, p391). If conceptual change is seen as a type of learning (Vosniadou, 2013, p1) then insights can be seen to result in a range of different types of learning. Some insights might be seen as resulting in understanding, meaning 'seeing the overall picture and how the parts relate to the whole' (Entwistle \& Nisbet, 2013, p9), whereas other insights may lead to an awareness of simpler connections. To encompass this range of possibilities insight is defined simply as an awareness of novel relations. The definition of insight used here will relate to sudden changes in conceptual relationships, without reference to emotion or scale of the change: An insight is an explicit awareness of novel relations between concepts that arrives with apparent suddenness and little conscious awareness of processing.

\subsection{Differentiating intuition and insight}

Though insight and intuition have a history of being used synonymously (Simon, 1986, p242; Fischbein, 1987, p5; Schooler \& Dougal, 1999, p281), contemporary writers are increasingly attempting to separate the two processes. For example, Liebermann argues: 
[I]ntuition must be distinguished from insight... insight is a process where one suddenly becomes aware of the logical relations between a problem and the answer. In the case of intuition, usually there is no insight into the logical relations, but simply an impetus, judgment, hunch, or behavioral response. That said, intuition is the subjective experience of a mostly nonconscious process that is fast, a-logical, and inaccessible to consciousness. (Liebermann, 2000, pp. 110-111)

Dane and Pratt (2007, p40) also distinguish the two processes, describing insight as when one '...consciously becomes aware of the logical connections supporting a particular answer or solution' which may be a lengthy process preceded by explicit, analytical thought whereas in intuition '...one is unable to consciously account for the rationale underlying the judgment that has arisen.' These differences might be summarised as follows:

\section{An intuition is a tacit hunch or feeling that influences thought with little conscious effort.}

\section{An insight is an explicit awareness of novel relations between concepts that arrives with apparent suddenness and little conscious awareness of processing.}

The term novel in the definition of insight refers to personal originality; returning to a previously experienced awareness is not an instance of insight. To illustrate the difference between intuition and insight consider the following problem (Jargocki, 1983, p30): A metal disc with a central hole (like a washer) is heated to a uniform temperature. Does the area of the hole increase, decrease or remain the same? On hearing the problem one may develop a feeling or hunch as to how the area of the hole will change. This may be based on knowledge that is difficult to articulate and be thought of as an intuition. On the other hand, if a solution comes to mind suddenly, perhaps after a period of incubation, and with little awareness of process, it may be described as an insight. A third possibility is the problem is solved through deliberate, conscious thought. Though they do so in different ways, both intuition and insight are processes by which the tacit influences the explicit, and therefore offer an opportunity for opening a discussion of tacit knowledge. The next two sections, will consider intuition and insight in more detail.

\subsection{The concept of intuition}

In order to develop an understanding of the concept of intuition in science education, I will begin by examining its role in the work of scientists. The position of intuition in science education will be examined by conceptualising intuition first as embodied cognition and secondly as abstracted rules. The relationship between tacit and explicit concepts in science education will be considered before examining the factors that promote and hinder intuition. After considering how intuition may be considered supportive and obstructive to the goals of school science, I conclude the section by proposing ideas to support productive intuition in the classroom.

\subsection{Intuition in the work of scientists}

This section, which examines reports of intuition from scientists, and section 4.1 which sets out a similar accounts of insight, must be read with the caveat that 
descriptions of changes in public models of science cannot be assumed to correlate with the manner in which psychological models change. Though Kuhnian revolutionary change has been linked to radical conceptual change in science education (e.g., Strike \& Posner, 1992; Nersessian, 1999), Kuhn himself, in his later work, advised against this conflation, instead proposing that 'revolutions should be described not in terms of group experience but in the varied experiences of individual group members' (Kuhn, 1993, pp. xii-xiii). It is this position that will be used for these sections: the descriptions of intuition and insight of scientists are descriptions of personal experiences: there is no intention to draw parallels between changes in public and psychological knowledge. As will be argued in section 3.5.2, these examples may prove to be useful exemplars for teachers to present to students who are learning how to integrate their own intuitions with the scientific ideas they are taught in school.

Several researchers report scientists' claims to have used intuition in their work (Goldberg, 1985, p28; Marton, Fensham \& Chaiklin, 1994; Wolpert, 1992, p56) though their reports may be referring to a range of phenomena, different from the definition of intuition used in this review. Experts in physics are described as having good 'physical intuition' (Larkin et al., 1980, p1335) and there are similar references to 'biological intuition' (Slatkin, 1974, p219; Jansen, 2001, p119; Ragan \& Chan, 2013) and 'chemical intuition' (Keserü, Soós \& Kappe, 2014; Catlow, 2013). A survey of papers published in physics journals between 2001 and 2010 found that the percentage of studies that used the words 'intuition,' 'intuitive' or 'counter-intuitive' varied between seven and nine per cent (Tallant, 2013, p2966). In an analysis of broadcasts by Nobel laureates between 1970 and 1986, Marton, Fensham and Chaiklin (1994, p460) calculated seventy-seven percent of the laureates either 'declare explicitly their belief in scientific intuition or they make comments about it, thereby taking its existence for granted.' Shavinina (2004) analysed how Nobel laureates in science achieved their breakthroughs and concluded intuition was a 'key aspect of scientific thinking leading to innovative discoveries' (Shavinina, 2004, p250).

Scientists themselves refer to the necessity of intuition: Max Planck proposed that the pioneer scientists must 'have a vivid intuitive imagination, for new ideas are not generated by deduction, but by an artistically creative imagination' (Planck, 1950, p109). The theoretical physicist Hideki Yukawa argued that abstraction couldn't occur just by itself 'but has to be accompanied by intuition or imagination' (Yukawa, 1973, p107). Several scientists report significant hunches that they are not subsequently able to justify. Rutherford, on being asked to support his claim that heavy water contains tritium, is reported to have roared: 'Reasons! Reasons! I feel it in my water!' (Rutherford quoted in Oliphant, 1972, p19). Watson (1980, pp. 99-101) described his intuition that DNA must be a two chain molecule since 'important biological objects come in pairs,' which, despite Crick's doubts and a lack of experimental evidence, lead him to began investigating two chain models of DNA.

Physicists value the power of physical intuition and refer to it as a decision-making tool: 'A physicist's intuition tells him that, if Einstein's principle is valid at all, it ought to be valid for the whole of physics, quantum-mechanical as well as classical' (Dyson, 1972, p646). Though the scientific method requires that results of intuition be verified, the processes that lead to novel ideas are often difficult to understand in retrospect; the process of coming to new scientific ideas is tacit (Polanyi, 1967, p536). For example, Jonas Salk, argued: 'we first sense and then we reason why. Intuition is an innate quality and it can be developed and cultivated' (Salk, 1983, p79). Science involves the interplay of intuitive and analytic processes and, both these modes of thought should be represented in the classroom. 
As I will argue is also the case for students, the testimony of scientists shows intuition can be an obstructive as well as a productive process. Rohrlich argued scientists such as Newton and Schrödinger continued to develop innovative theories despite misgivings and had to suppress an intuition or 'feeling of what's right' (Rohrlich, 1996, p1624). A great challenge for scientists and school students alike is in knowing when intuitions may be trusted, and used to facilitate understanding, and when intuition must be ignored and overruled by analytical thought. As well as scientists themselves, philosophers of science have argued for the role of intuition. Feyerabend (1970, p90) promoted a model of science without a single, defined method but as an arational process driven by 'esthetic judgments, judgments of taste and our own subjective wishes.' Popper $(1959, \mathrm{p} 8)$ argued discovery 'contains an "irrational element," or a "creative intuition."' Given the prominent role of intuition in scientific discovery, the next section examines the position intuition may play in science education.

\subsection{Intuition in science education research}

Despite the reported significance of intuition, there is a perception that it is unscientific and akin to mysticism (Claxton, 1998, p217) Laughlin (1997, p22) has claimed that '[s]omewhere in the process of formulating the positivist project, the intuition baby was thrown out with the metaphysical bath water.' This review hopes to begin the process of restoring intuition to its important role in science and science education. Teaching science is challenging: in addition to the representations of public science (for example the statements in a syllabus or a textbook), tacit knowledge may be an important part of scientific knowing (Polanyi, 1966/2009, p20). Polanyi (1966, p5) used an analogy to describe the difficulty of science teaching: just as one may be able to ride a bicycle without having access to the kinaesthetic knowledge that makes balance possible, a teacher may have an excellent understanding of explicit scientific propositions but lack awareness of their implicit understandings. Polanyi insists that some of the expertise of scientists 'cannot be put into words, nor even conveyed by picture' (Polanyi, 1966, p5). The next sections deal with two models of intuitive knowledge in the context of science education: as embodied cognition and as abstracted rules. It is not my intention to make claims for the superiority of either model, rather to present them as two approaches for understanding an under-researched concept.

\subsubsection{Intuition in science education research: intuition as embodied cognition}

It is possible to account for the tacit nature of intuitions if they are conceptualised as information that is encoded non-verbally. An early precursor of this idea is found in Merleau-Ponty's (1945/2005, p166) notion of 'knowledge in the hands,' the embodied knowing that allows a typist of find the keys without conscious thought. The embodied cognition hypothesis (Mahon \& Caramazza, 2008, p60, italics in original) posits that 'conceptual processing... is sensory motor processing,' and that conceptual data is inextricably bound up with tacit, kinaesthetic memories. The plausibility of a link between intuition and the motor system is supported by evidence that suggests activation of the motor system is fast and automatic (Mahon \& Caramazza, 2008, p61) and indeed two models of tacit processing in science education, diSessa's (1993) phenomenological primitive account and Clement's (2008) model of intuition, discussed below, invoke kinaesthetic resources. A significant problem for the embodied cognition hypothesis is how abstract concepts, such as energy, may be constructed from sensorimotor resources. Dove (2011, p11) has suggested that language may act as a form of 'dis-embodied cognition' that 'extends cognition' beyond the concrete and perceptual to form abstractions. It is through the mechanism of language, and analogy in 
particular, that perceivable attributes of flow or substance are associated with an abstract concept such as heat (Driver et al., 1994, p138). In this section I will examine theories for the development of intuitions as embodied cognition and present a number of different constructions of phenomenological knowledge in science education.

Research in science education has shown that learners possess concepts about the physical world prior to teaching (McCloskey, 1983; Driver et al. 1994). Such concepts have been called 'intuitive theories' (McCloskey, 1983, p123; Sherin, 2006, p535) though a variety of terms such as 'misconception,' 'alternative conception' and 'preconception' (Kuiper, 1994, p280) have also been used. Such knowledge may be nonconscious, for example, the mental models that form part of Simon and Simon's (1978, p224) model of physical intuition may be, to some extent, tacit (Fischbein et al., 1990, p24). The 'perceptual/motor schema' that Clement (2008, p215) suggests are a part of intuitive reasoning are also resistant to verbal explication and transfer.

Links have been proposed between intuitive knowledge and physical experience with researchers speculating that intuitive knowledge is formed partly through practical physical experiences (Driver, Guesne \& Tiberghien, 1985, p2). It has been suggested that some kinaesthetic intuitions may develop in early childhood: Von Hofstein and colleagues (1998) reported that infants aged 23-26 weeks tended to expect the linear motion of an object to continue in a straight line at constant speed. Infants can also extrapolate both circular motion at constant speed (von Hofstein, 1983) and sinusoidal motion (von Hofstein \& Rosander, 1996). The degree to which these intuitions are innate or acquired through experience is an open question (Preece, 1984). Though intuitions regarding the nature of motion may be of predictive value for infants, they can interfere with later scientific learning (see, for example, McCloskey, 1983; Driver et al., 1994). As students progress, their initial intuitions can be conceptualised as being tuned towards expertise (diSessa, 1993, p114) giving rise to a 'U-shaped' model of the usefulness of intuition over time (Baylor, 2001). Baylor (2001) argued that immature and mature intuitions are both fruitful tools for understanding reality (the arms of the ' $U$ '), yet there is an intermediate phase in which intuitive concepts clash with formal learning (the dip in the ' $U$ '). A different position suggests early intuitive understandings are never fully supplanted by formal scientific knowledge (Goldberg \& Thompson-Schill, 2009; Shtulman \& Valcarcel, 2012): research shows that even experienced scientists, when forced to answer rapidly, may revert to intuitive understandings (Kelemen, Rottman \& Seston, 2013). The level of agreement between physical intuitions and accepted scientific concepts may vary from person to person. Some evidence suggests that there is moderate correlation between a person's performance on different types of tasks testing physical intuition (Riener, Proffitt \& Salthouse, 2005, p744). There is also evidence that males perform better than females on certain types of tests of intuitive physics (Robert 1990; Riener, Proffitt \& Salthouse, 2005, p744). There is scope for further research into the manner in which intuitions are formed and in particular the question of whether more successful science students are those whose initial physical intuitions more closely resemble the accepted scientific models.

Lakoff and Johnson (1980, p48) have proposed that complex concepts are partially understood through metaphors with physical experience (for example 'UNDERSTANDING IS SEEING'). They have argued that embodied metaphors such as 'MORE IS UP' are 'deeply embedded in our culture' (Lakoff \& Johnson, 1980, p22). In science education, Watts and Taber (1996) proposed the explanatory Gestalt of essence (an echo isn't caused: it just happens naturally), and Anderson (1986) suggested the experiential Gestalt of causation (objects are affected by agents). It may be that humans construct understandings of complex concepts by recruiting experiential resources. An alternative model of embodied knowledge is that of the phenomenological primitive (p- 
prim) developed by diSessa (1993) and described above. He argues that '[i]n dealing with the physical world, humans gradually acquire an elaborate sense of mechanism-a sense of how things work, what sorts of events are necessary, likely, possible, or impossible' (diSessa, 1993, p106) and these interactions result in 'little" pieces of intuitive knowledge' or p-prims (diSessa, 2000, p91). It is claimed that a student may have 'hundred if not thousands' (diSessa, 2000, p93) of p-prims which interact to allow students to make judgements. P-prims may be difficult to describe in language as they are kinaesthetically or visually encoded (diSessa, 2000, p96). This difficulty in accessing p-prims may explain why a student might struggle to explain their reasoning beyond stating 'that's the way things are' (diSessa, 1993, p112). It is also argued that p-prims are not discarded as a learner advances, rather the p-prims are 'tuned towards expertise' (diSessa, 1993, p114), that is, the expert scientist retains the use of intuitive knowledge but it has become part of an expert mental model.

John Clement's (2008) model of intuition argues that a student's kinaesthetic representations of physical situations may underlie intuition and explain its implicit nature. He presents an excerpt from a transcript of an experienced physicist solving a problem:

You don't have to know any formulas to see that...God almighty! Of course it [the wider spring] goes way down. You know. How could it do otherwise?

That's a seat-of-the-pants feeling I would trust beyond any of it.... I would bet a thousand to one. (Clement, 2008, p207)

Clement supports his kinaesthetic hypothesis by reporting '...subjects spontaneously use terms like "imagining," "picturing," "hearing," a situation or "feeling what it's like to manipulate" a situation' (Clement, 2008, p209). He argues that those engaged in problem solving may be running 'imagistic simulations' (Clement, 2008, p210) or mental simulations based on motor sensations to develop a clearer understanding of a problem situation.

It has been argued that the grounding of intuitions in kinesthetic sensations may lead to a tendency to focus on physical features and a difficulty in engaging with abstraction. Chi and Slotta (1993), like diSessa, make the case for an intuitive physics that is robust and developed out of physical interaction with reality. They assert that 'retrieval of intuitive knowledge is driven largely by surface features' (Chi \& Slotta, 1993, p250). Chi's earlier research reported that novice problem solvers tended to focus on surface features of a problem whereas experts were more able to move beyond specific details to develop categorisations of problems by 'second order features,' that is, features not explicitly stated in the problem (Chi, Feltovich \& Glaser, 1981, p142). They claim that experts develop a 'reading' (categorisation) of the problem 'early' in the process: one expert categorised a problem after having read only twenty percent of the text (Chi, Feltovich \& Glaser, 1981, p145). It could therefore be argued that experts can intuit the significant underlying structure of a problem rapidly, whilst novices' intuitions are incorrectly triggered by the concrete features of a problem. The ability to perceive underlying structure, and move beyond concrete details, may be a key component of the development from novice to expert intuition (Brock, 2006). The nature of such abstracted structures as a basis for intuition will be discussed in the next section.

\subsubsection{Intuition in science education research: intuition as abstracted rules.}

In contrast to intuitions as embodied cognition, various authors suggest intuitions may be automated procedures for reaching conclusions rapidly. Such 
processes can be thought of as a 'heuristic' or 'a simple procedure that helps find adequate, though often imperfect, answers to difficult questions' (Kahneman, 2011, p98). For example, the expectation bias (Jeng, 2006), which is a tendency for observations to be biased towards what the observer expects to see, has been observed in students' reactions to anomalous data in the classroom (Champagne, Gunstone \& Klopfer, 1985, p65). Though such heuristics are possibly also formed through experience of the world, their abstract and non-kinesthetic nature set them apart from the concepts of embodied cognition discussed above. The principle of implicit rules that guide cognition has appeared in the literature in a number of different conceptualisations.

The qualitative physics model (De Kleer \& Brown, 1984, pp. 7-8) was an attempt by artificial intelligence researchers to model the complex processes that lead to 'commonsense physical reasoning' (Forbus, 1984, pp. 85-86). The authors of the model claim a 'qualitative causal calculus,' a set of simple rules and principles, underpins physical intuition in much the same way as a set of simple operations is used to construct a complex computer program (De Kleer \& Brown, 1984, p8). A different conceptualisation is that of intuitive rule theory developed by Stavy and Tirosh (Stavy et al., 2006). They identified rules which students used that led to incorrect responses to problems; the rules were categorised as intuitive as learners felt the rules were 'self evident' and lead to highly confident responses to the exclusion of other possibilities (Stavy et al., 2006, p418). The rules they cite (for example: more $A$ - more $B$ and same $A$ same $B$ ) are seen as unconsciously constraining complex calculations. Based upon some preliminary data, they hypothesise that intuitive rules are universal across cultures (Stavy et al., 2006, p433). Claxton (1993, p63) has proposed that learners develop minitheories that, unlike the stable rules described above, are fragmented and constantly shifting. Minitheories are compared to computer programmes in that they provide a set of procedures to follow in different circumstances, though these procedures are seen as implicit, in the form of intuition and impulse (Claxton, 1993, p47). A collection of minitheories can be seen as producing a 'gut science,' which is contrasted with 'school science, based on the symbolic and idealised world of the science classroom' (Claxton, 1993, pp. 51-53). The nature of relationship between intuitive knowledge and the statements of school and public science will be considered in the next section.

\subsubsection{Intuition in science education research: the entanglement of explicit and tacit knowledge}

Up to this point, I have considered tacit and explicit knowledge as binary positions. In this section I will consider the consequences, both for teaching students and for training teachers, of a conceptualisation of knowledge that exists along a continuum from entirely implicit to entirely explicit (see figures 2 and 3 ). 


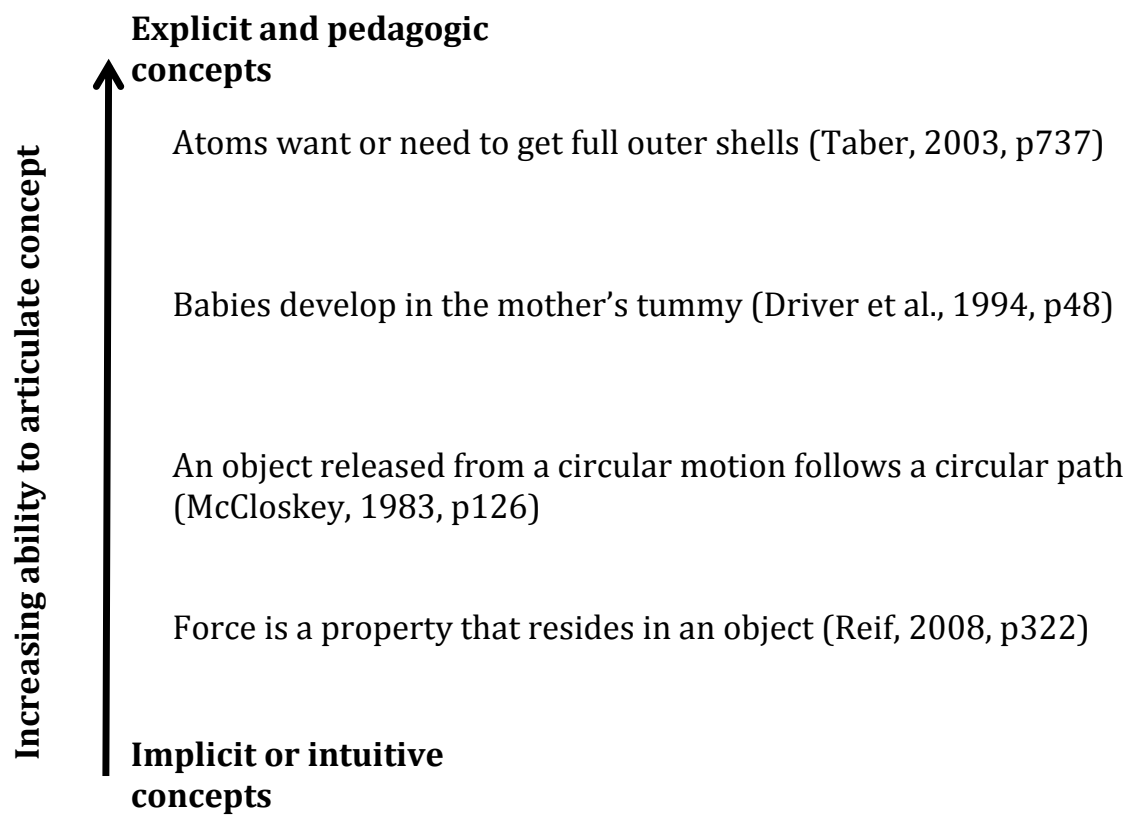

Figure 2: Speculative range of availability of conceptions

Students may possess concepts that are largely explicit, for example they believe that atoms 'want' to have full outer shells (Taber, 2003, p737). Taber (2001, p166) has argued that some of the more explicit conceptions students hold may be directly caused by teaching and has labeled them pedagogic learning impediments. By contrast, the presence of other concepts may be inferred by researchers from students' utterances whilst the students themselves have little explicit awareness of their existence, for example the concept of force as a property residing in an object (Reif, 2008, p322). It may be useful to differentiate between concepts that have greater or lesser degrees of explicit availability to students.

This model may be developed a step further by assuming that some concepts may exist as a complex combination of implicit and explicit facets (Berry \& Broadbent, 1988, p271). For example, the concept of force, may involve explicit statements of Newton's laws but also elements of tacit knowledge (see figure 3). The lower half of the figure represents the expected development of the concept: a novice's understanding of force will be largely tacit but as they move towards expertise the explicit components of the concept become dominant, though it is assumed they will retain tacit knowledge that is developed towards expert intuition. Crucially, intuition can be seen as the mechanism by which tacit knowledge may link to conscious understandings of a concept. 

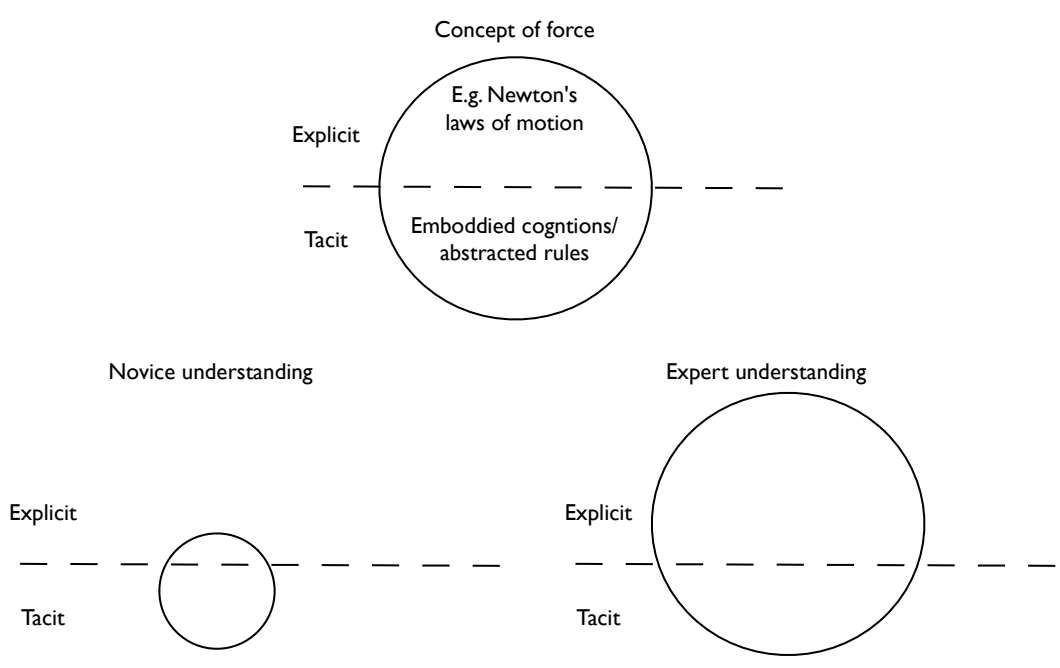

Figure 3: A concept as a combination of tacit and explicit components and the development of this concept with expertise

A conceptualisation of knowledge as a combination of implicit and explicit components may explain the challenge Feynman reported in transferring his expert knowledge:

I don't know how to tell you something that will transform you from a person who can't analyze new situations or solve problems, to a person who can...But in the case of physics, I can't transform you from somebody who can't to somebody who can, so I don't know what to do.

Because I intuitively understand what's going on physically, I find it difficult to communicate.

(Feynman, 2013, p69, italics in original)

The fact that explicit propositions are entangled with tacit knowledge explains how it is possible that: 'the students had memorized everything, but they didn't know what anything meant' (Feynman, 1985, p 212). Tacit-explicit entanglement of scientific concepts, may account for the gap between knowing and understanding: Kosso (2002, p39) claims '...knowledge is the sustenance of science. But knowledge without understanding is pretty thin soup.' Kosso (2002) imagines a hypothetical being who knows everything but doesn't understand anything and might be represented by a large circle entirely in the explicit section of figure 3. Kosso's imaginary knower illustrates the claims that acquisition of facts alone is not sufficient for understanding (Bransford, Brown \& Cocking, 2000, p9). Singh (2002, p1105) reports that even physics professors who have 'vast amounts of physics knowledge' can lack physical intuition when encountering novel problems. The extent to which tacit knowledge might explain the gap between knowledge of facts and understanding is an interesting area for future research. Such research would be challenging as a constructivist model of scientific knowledge suggests tacit knowledge, as well as being difficult to articulate, is likely to be personal:

Science exists as public knowledge...When individuals read (or are told) this public knowledge, they interpret and internalize it in their own way. ... the understanding of each of those bits of knowledge, the meanings that we give to them, are idiosyncratic to some extent. Thus, our private 
understanding is not fixed; it is not the same as that of other people; it is not the same as public knowledge. (West, Fensham \& Garrad, 1985, p30)

Furthermore, tacit-explicit compounding is a pertinent issue for those training science teachers. Shulman $(1986, \mathrm{p} 9)$ noted that effective teachers require more than a knowledge of subject content and defined an additional form of understanding, pedagogical content knowledge, as 'ways of representing and formulating the subject that make it comprehensible to others.' Yet this knowledge may be partly tacit (Cohen \& Yarden, 2009, p134; Loughran, 2006, p109) and therefore not easily fostered in trainee teachers. Models of skill acquisition, for example the Dreyfus \& Drefyus (1980) fivestage model, suggest novices begins by learning explicit rules but the attainment of mastery requires the ability to use of holistic recognition and intuitive decision making. Indeed, Hammond's (1980) model of cognitive continuum argues high performance results from an ability to combine explicit and implicit modes of reasoning.

The difficulty of fully articulating expert knowledge has resulted in other fields including nursing (McCutcheon \& Pincombe, 2001) medicine (Hall, 2002), management (Sadler-Smith \& Burke, 2009) and law (Glöckner \& Ebert, 2011) developing research programmes investigating the role of intuitive knowledge in effective practice. Effective teacher education has pre-empted Kahneman's project of explicating implicit heuristics: teacher educators have long attempted to explicate the intuitive rules-of-thumb that lead to good teaching. In addition to the varied models of teacher mentors that already exist, it may be useful to emphasise their difficult role both as explicators of the tacit, and developers of productive intuitions (for a detailed discussion of the role of intuition in teaching practice see: Atkinson and Claxton, 2000). The next section focuses on understanding the conditions that may promote the use of intuitive thinking.

\subsection{Conditions that promote the use of intuition}

People do not engage in intuitive thinking all the time nor is cognition always conscious and reasoned. In this section I will examine conditions that encourage an intuitive mode of thinking: the first section examines if intuition is a way of coping with high cognitive load, the second section debates evidence concerning whether individuals display fixed preferences for intuitive thinking. The final section examines how understandings of the nature of science might encourage or hinder intuitive thought.

\subsubsection{Intuition is used when cognitive demand is high}

It has been argued that whilst deliberate thought is effortful, intuition offers a way of reaching decisions quickly, and with little effort, when cognitive load is high (Kahneman, 2011, pp. 31-38). Several studies (Kelemen, Rottman \& Seston, 2013; Shtulman \& Valcarcel, 2012; Goldberg \& Thompson-Schill, 2009) have demonstrated that experienced scientists reverted to teleological explanations of natural phenomena when their information processing resources were artificially limited. For example, it is reported that a limited response time (Kelemen, Rottman \& Seston, 2013; Goldberg \& Thompson-Schill, 2009) is linked with activation of intuition. The effect that time constraints in lessons and assessments may have in encouraging or discouraging the use of intuition is an area that would benefit from further research; section 3.3 will examine evidence that an incubation period may facilitate insights. The next section examines the proposition that some people are more inclined than others to make use of an intuitive style of thinking. 


\subsubsection{Is there an intuitive learning style?}

In addition to the effects of cognitive load, a reliance on tacit hunches may be a predisposition that is stronger in some individuals than others. The construct of an intuitive learning style suggests some students are predisposed to intuitive thought, whilst others will have a preference for explicit reasoning. The construct of learning styles has been criticised for many years for the lack of evidence to substantiate claims made by its proponents (Stahl 1999; Dembo \& Howard, 2007); the existence of an intuitive learning style in scientific thinking seems also to be thinly supported by evidence. Jung (1971) proposed a juxtaposition between a sensing preference, favouring observation and gathering evidence through the senses, and an intuitive preference, privileging indirect perception via the unconscious. Though the intuitive-analytical dimension disappeared from mainstream research for a time (Allinson \& Hayes, 1996, p2), it has reappeared in some models of learning styles. For example, Felder and Silverman (1988, p675) describe some engineering students as having a 'sensory' preference favouring 'sights, sounds and physical sensations' whereas other 'intuitive' students value internal information, 'possibilities, insights, hunches.' Two small-scale studies (O'Brien, Bernold, \& Akroyd, 1998; Wankat \& Oreovicz, 1993) of engineering students used the Myres-Briggs Type Indicator to report the proportion of a population that displayed an intuitive preference. Other studies, again from very small sample, suggest students exhibit stable preferences for either analytical or intuitive styles in problem solving in physics (Thorsland \& Novak, 1974) and students with an intuitive preference preformed better on the more abstract sections of a course (Felder, Felder $\&$ Dietz, 2002, p6).

The difficulty with such research is there is little evidence for a reliable link between an expressed preference for a particular style of thought and a consistent application of that style in the classroom. Kahneman's (2011) description of cognition as the interplay of two systems, one deliberate and one automatic, seems to be a more useful model. Indeed, several authors have suggested that intuition and analysis should not be seen as mutually exclusive processes but systems that interact in the development of understanding (Hodgkinson et al., 2009, p346; Bruner 1977, p58; diSessa, 1993, pp. 114-115). It seems likely that learners will make use of intuitive and explicit knowledge at some times and in some contexts. Akinci and Sadler-Smith (2013, p211) argue that some kinds of tasks (where time is limited and information is incomplete) may require the use of intuition whereas other tasks (where there is no time pressure and complete information) are more likely to be solved through deliberate thought. Hence, rather than opposing positions, they imagine intuition and analysis as two orthogonal axes (Akinci \& Sadler-Smith, 2013, p218): individuals may be both highly intuitive and highly rational depending on the context. Rather than building a model of a general preference towards an intuitive or deliberate style, a more fruitful direction for research would seem to be to understand the specific contexts and contingencies that trigger the use of tacit or explicit thinking.

\subsubsection{Understandings of the nature of science and the use of intuition}

There are indications of a correlation between the view of science held by teachers and students and their attitude towards the use of intuition. Beliefs about the nature of knowledge and knowing have been studied for over thirty years (Rule \& Bendixen, 2010, p95) and are known as personal epistemologies (Hofer, 2001, p355). There is a body of evidence indicating students' epistemological beliefs about science can affect their academic performance (Mason et al., 2013), and in general more complex epistemologies have been linked to higher academic achievement (Hofer, 2001; 
Schommer, 1990; Kardash \& Howell, 2000). Some research (Qian \& Alvermann, 2000; Qian \& Alvermann, 1995; Songer \& Linn, 1991) indicates students' beliefs about the nature of the science influence their approach to learning in the subject.

Data from a number of small-scale studies suggest a correlation between students' understanding of the nature of science and their attitude to the use of intuition. For example, Tsai (1998, p478) reports, in a small sample, students aligned with a constructivist position of the nature of scientific knowledge were more likely to believe scientists came to ideas through intuitions or flashes of insight than students with an empiricist model. A number of case studies go further than this and imply a correlation between personal epistemology and approach to learning. The case of two students, $A$ and $B$, with different epistemologies of physics is presented by diSessa (1985). Like Hammer (1994, p152), diSessa (1985, p107), argues epistemologies of physics, at least for novices, may themselves be tacit. Student A believed that 'knowledge resides in the equations and numbers' and viewed qualitative knowledge 'with suspicion' (diSessa, 1985, p103). Contrastingly, student B is reported as valuing 'real understanding' and having a strong sense of the importance of qualitative understandings (diSessa, 1985, pp. 103-105). Student B claimed to work through a problem 'intuitively' at first and would 'compare his intuition with the detailed answer he was sure of in order to "save the good intuitions and find out the bad ones"' (diSessa, 1985, p104). Student B gives an account of the experience of intuition claiming he never explicitly choses equations but: 'They just seem to 'pop up' when I need them' (diSessa, $1985, \mathrm{p} 104)$. In reflecting on the students' class projects, diSessa $(1985, \mathrm{p} 105)$ reported student A's work contained a proof that was not extended beyond what was given but student B's project was one of the best he had encountered.

Lising and Elby (2005, p376) argue a students' epistemology may cause the construction of a 'wall' between their intuitive and formal reasoning that leads to a failure to check calculations against everyday reasoning. Another case study that implies some correlation between personal epistemology and the use of intuition concerns two students: Ellen and Liza (Hammer, 1989). Ellen wanted to integrate the physics in her course with her own intuitions and reported she 'felt,' or could just 'see' an answer (Hammer, 1989, p667). Liza was content to learn facts and formulas based on the authority of the lecturer (Hammer, 1989, pp. 665-666). Liza's 'methodical approach' meant she performed better on routine problems than Ellen, but Ellen's performance was better than Liza on qualitative problems. In a further case study, Hammer (1994) reports that Roger, who regarded physics as weakly coherent and given by authority, did not try to resolve a difficulty he encountered in solving a problem. In contrast Tony, who regarded physics as conceptual and coherent, is described as examining 'his intuition to see how it might be misleading him' (Hammer, 1994, 166). A correlation between an understanding of science that conceptualises the discipline as involving more than rote learned knowledge and the use of intuition may be a case of codevelopment rather than causation: both personal epistemologies (Perry, 1970; Moore, 2002), and some models of intuition (Baylor, 2001; Dreyfus \& Dreyfus 1980), are expected to develop with experience.

Students' beliefs about the role of intuition may be influenced by the assumptions, implicit or explicit, their teachers hold about the nature of knowledge (Hofer \& Pintirch 1997, p109; Russell \& Munby, 1989, p112). For example, one undergraduate student reported feeling alienated from his studies due to a desire to gain an intuitive sense of engineering whilst taking a course that valued memorisation (Danielak, Gupta \& Elby, 2010). Pomeroy (1993) conducted a survey of scientists' and teachers' beliefs about the nature of science that included questions about the place of intuition in science. She grouped the questions into two clusters: traditional and 
nontraditional views of science education. A selection of the statements from those clusters are shown below:

Traditional views of science education

- Science learning should proceed, wherever possible, hierarchically.

- Children in science should be discouraged from "wild" ideas and encouraged to think carefully and logically. (Pomeroy, 1993, pp. 266-267)

Nontraditional views of science education

- Intuition plays an important role in scientific discovery.

- Legitimate scientific ideas sometimes come from dreams and hunches..

- Non-sequential thinking, i.e. taking conceptual leaps, is characteristic of many scientists (Pomeroy, 1993, p267).

The results suggested that scientists held the most traditional views of science with teachers, and primary teachers in particular, more likely to hold nontraditional views (Pomeroy, 1993, p269). Pomeroy (1993, p272) attributed this difference to the emphasis given to constructivism in science education courses. Though there is little evidence for a causal link between personal epistemologies and the effective use of tacit knowledge, section 3.5.2 will consider studies that have attempted to support students' use of tacit knowledge by increasing their awareness of epistemological assumptions. This section has argued both cognitive load and the models of science students possess may affect their use of tacit knowledge. This might be seen as part of the move proposed by Taber (2009, p327) in science education research away from the 'butterfly collecting' stage of describing intuitive ideas towards understanding the contingencies of their activation.

\subsection{Productiveness of intuition}

In section 3.2.1, I reported models that conceptualised intuition, at different stages in a student's development, as supporting or hindering the learning of canonical concepts. Bruner (1977, p60) held the view that "some intuitive leaps are "good" and some are "bad" in terms of how they turn out.' He added that it takes particular sensitivity in a teacher to distinguish between an 'interestingly-wrong' leap from a 'stupid or ignorant' mistake (Bruner, 1977, p68). By contrast, Taber (2004, p124) proposes that intuitive physics theories should not be thought of as 'wrong' but rather as different interpretations of physical reality. The phenomenological knowledge that can at first interfere with learning may be formed into a basis for intuitive expertise. Some intuitive concepts will be constructive and can be used to 'anchor' future learning (Clement, Brown \& Zietsman, 1989). P-prims, diSessa (1993, p114) argues, are not discarded but 'tuned towards expertise.' Interpretations of concepts that do not match accepted scientific models, for example a substantive ontology of gravity, can contribute to learning (Gupta, Elby, Conlin, 2014). Yet students may feel alienated from the science classroom when their initial intuitions differ from those of their teachers (Taber, 2004, p124); what appears to make effortless sense to teachers may be counter-intuitive for students. Teachers have a role to play in helping students understand the nature and fruitfulness of their intuitive ideas (see section 3.5.2). Rather than seeing tacit knowledge as something that needs to be eradicated, teachers should facilitate the development of expert intuitions in their students (Hammer \& Elby, 2003). The next section examines ideas that may be used to foster productive intuitions in science students. 
As has been argued, intuition is 'an essential component of expertise in physics' yet is 'difficult to convey' (Singh, 2002, p1103). Cultivating physical intuition has been described as a 'cultural norm' and part of the hidden curriculum of physics (Redish, 2010, p3). In ecology education, authors argue for the importance of developing an intuitive sense of the natural world (McLaughlin, 2005, p52; Baldwin, 1997). Yet it has long been felt the 'formalism of school learning' has ignored the role of intuition (Bruner, 1977, p58). Discussed below are a range of strategies that may encourage the use of productive intuitions in the science classroom: using simulations and practical work and presenting a model of the nature of science that is accepting of intuition as a route to understanding.

\subsubsection{Intuition and the use of simulations and practical situations}

The role of physical experience in generating intuition has been highlighted earlier in this article. Yet, it is reported that students may learn science merely as abstract symbolic knowledge, divorced from physical and implicit concepts, and so develop limited understandings (Black, 2010, p45). Black (2010, p51) argues that the use of computer simulations (for example, a simulation of a roller coaster showing the energy changes that occur) can help students to develop 'grounded cognitions' which include a "feel" for what they are learning. Fischbein (1987, p103) has claimed that 'what one cannot imagine visually is difficult to realise mentally' and argued visualisation may be the cause of the immediacy of intuition. Visual simulation based learning may therefore aid in developing intuitive understanding (Swaak \& Jong, 1996, p344). DiSessa (1986, p210) created a simulation, dynaturtle, which allowed students to interact with a world without drag forces and claimed it 'is the best we can do at making some of the real objects of science experiential.' He argues that experiences in simulations are not essentially different form experiences in the real world and can be used to scaffold students' intuitive understanding of science concepts (diSessa, 1986, p226). Another attempt at using simulations to alter students' tacit knowledge was carried out by Howe, Devine and Taylor Tavares (2013) who used a computer simulation to visualise students' predictions for the paths of falling objects. Students who predicted incorrect paths were often able to intuit their mistakes from viewing a simulation and change their prediction.

Practical work may also play a role in developing intuition. The nature of scientific knowing could be argued to include 'a component that is experiencedependent in a very personal sense' and therefore 'not directly teachable' (Hodson, 1993, p120). As Wellington and Osborne (2001, p7) argue 'the touch and feel of practical work cannot be put into words,' and some scientific ideas may be conveyed more effectively through gestures and body language than through talk or pages in a book. Rich and well-structured practical experiences may serve as the basis for the ability to run effective mental simulations. Thought experiments are seen as powerful tools for learning and rely on the ability to retrieve 'experiential knowledge, in the form of visual or bodily images, of which students are not necessarily aware' (Reiner \& Gilbert, 2000, p490). Practical work may be conceptualised as developing a library of experiential resources that can be used to guide future intuitions.

\subsubsection{Intuition and teacher and student views of the nature of science: presenting a model of science that values intuition}

In section 3.3.3, I presented some evidence for a correlation between students' perceptions of the nature of science and their use of intuitive resources. Though this link is not necessarily causal several authors have proposed increasing students awareness 
of epistemological assumptions to promote a more productive use of intuition. Hammer and Elby (2003) recommend teachers make students aware they will come to the classroom with pre-existing intuitions and explicitly teach the process of reconciling intuitions with scientific models. For example, they suggest informing students: 'Very often you'll have a sense that a ball or some other object ought to move in a certain way, but you'll have trouble putting your finger on why you have that sense' (Hammer \& Elby, 2003, p64). They propose setting questions that encourage students to engage with their tacit knowledge by explaining, for example, in what sense the intuition that there is a force in the direction of motion is a useful or misleading intuition (Hammer \& Elby, 2003, pp. 78-79). Modeling the process of tuning a raw intuition that 'the car reacts twice as much during the collision' into a more refined expression 'the car feels twice as large a force during the collision' (Hammer \& Elby, 2003, p81) would seem to be a potentially useful teaching technique, though the authors themselves highlight there is no evidence to support the effectiveness of their approach (Hammer \& Elby, 2003, p75). Tirosh, Stavy and Cohen (1998) suggested making students aware of an argument that conflicts with their intuitive rules but they report this technique caused limited conceptual change and only reconfirmed the stability and resistance to change of intuitive rules.

Teachers modelling their own use of intuition in developing understanding and problem solving (Felder \& Silverman, 1988, p68) may provide an opportunity to introduce students to the concept of tacit knowledge. A useful demonstration might involve a teacher discussing their initial intuition and then modelling the use of explicit, analytical methods to check the fruitfulness of the initial hunch (Bruner, 1977, p58). It may be beneficial, once students are comfortable with routine problem solving to observe teachers engaging in intuitive attempts to solve challenging problems (Fensham \& Marton, 1992, p117). Another approach is the use of problems that raise common 'alternative' intuitions and then discussing the process of tuning those intuitions to fit with scientific ideas (Hammer \& Elby, 2003, p81; Campanario, 1998; diSessa, 1985, p112).

Finally, it may be beneficial, to present a model of science, as described by Feyerabend, which allows 'esthetic judgments, judgments of taste and our own subjective wishes' (Feyerabend, 1970, p90). A presentation of the use and abandonment of intuitions by scientists might, not only present a human and engaging version of scientific history, but also foster an understanding of how to manage tacit knowledge in students. Noble Laureate, Dudley Herschbach argued education systems did not have the means to foster intuition and he recommended encouraging students to see learning as a process of developing new perspectives rather than focusing on reaching a 'right' answer (Herschbach, quoted in Fensham \& Marton, 1992, pp. 119-120). If science is presented as a subject that only requires rote learning and the application of formulaic methods, students will become frustrated when they encounter problems that cannot be solved by routine methods. The suggestions presented above are not presented with any evidence of effectiveness in educating intuition. As Bruner (1977, p59) remarked over a quarter of a century ago '...much more work is needed to discover how we may develop the intuitive gift of our students.'

\subsection{The concept of insight}

Research into insight has a long history, beginning with the work of the Gestalt psychologists (Sternberg \& Davidson, 1995, pxv), and there continues to be an active research program investigating insightful problem solving (Chu \& MacGregor, 2011). In 
the following sections, I will present a summary of the role of insight in the work of scientists before examining insight's relationship to sudden conceptual change and the development of conceptual connections. After presenting some examples of insight in the science education literature, I will examine how educators may attempt to support the process in the classroom.

\subsection{Insight in the work of scientists}

The discoveries of Archimedes, Darwin, Kekulé, Leowi and Watson have been linked to insight (Gruber, 1995; Ramsland, 2012). Moments of insight have been described as being accompanied with feelings of pleasure: '...it was the confluence of the investigation of such different phenomena...When it all suddenly "clicked" it was the highlight of my scientific career' (Keller, 2000, p8752). The rewarding nature of insight is claimed to explain why scientists are prepared to spend long periods of time attempting to solve challenging problems (Metcalfe \& Weibe, 1987, p238). Though such "Eureka" moments have attraction, it is worth remembering that they are rare events and many discoveries have been made in a more gradual manner (Koshland, 2007, p762). Moreover, many of these apparently sudden insights (for example, Kekulé's visualisation of the structure of benzene) have followed years of immersion and conscious effort in solving a specific problem (Sadler-Smith, 2008, pp. 70-72). Classroom science may proceed in a similar manner; students will, most of the time, work in a rational and deliberate manner, yet, have occasional moments of insight.

\subsection{Insight in science education research}

It is difficult to find reports of students' insight in the science classroom. Anecdotally teachers report students experiencing moments of sudden clarity:

I have come to believe that a key element in a memorable classroom experience for most people is what I call the "Ah-Ha" experience. Time and time again people tell me of an experience in a classroom setting when some concept suddenly clicked for them. It may have been the sudden recognition of the power of vector notation, or the insight that all of statics is contained in just a few equations that sum forces and torques and set them equal to zero (Fuller, 1993, p300).

Joe Redish, in a discussion of physics teaching, clearly refers to moments of insight:

Often you have to work for a long time without feeling that you are making much progress. Then, suddenly, everything falls into place and it all makes sense. But until the "click," you can't be sure how much time you need to "get it" and it's difficult to plan. Students first have to learn what understanding the physics feels like and be slowly drawn into working hard enough to learn harder and harder topics (Redish, 2003, p68).

The next two sections will consider reports of moments of insight in science classrooms in the light of two theoretical models: insights as moments of sudden conceptual change and insights as the formation of novel connections. These processes are related if one assumes concepts acquire their meaning by being embedded in a network of concepts (Taber, 2013, p232), then development of conceptual connections is a feature of conceptual change (Tyson et al., 1997, p391). For example, Zeitsman and Clement $(1997$, p86) argue the development of conceptual connections in an insight, 
resulted in conceptual restructuring. The next section examines the link between insight and conceptual change.

\subsubsection{Insight in science education research: insight as sudden conceptual change}

Several researchers have linked sudden conceptual change to moments of insight (Dubar, 1995, p379; Fischbein, 1987, p5; Clement, 1989, p341), for example Fisher and Moody $(2002$, p65) describes an insight as 'the occasion in which a constellation of elements suddenly and instantaneously arrange themselves in a new configuration.' Conceptual change in science education has been an area of intense research and debate (Duit \& Treagust, 2003; Treagust \& Duit, 2009). There have been several models of conceptual change that contrasted two distinct processes of change. West's (1982) categorisation of conceptual change as evolutionary or revolutionary, a distinction used by several authors subsequently (Özdemir \& Clark, 2007, p354; Wiser \& Amin, 2001, p332; Nussbaum, 1989, p538), carries an implication of difference in speed of change. For example, Duit $(1994$, p56) links evolutionary change with continuity and revolutionary change with discontinuity. However for others, the revolutionary model is defined as the complete replacement of one concept by another, more fruitful concept (Caravita \& Halldén, 1994, p90) and the change may be 'time consuming and lengthy' (Özdemir \& Clark, 2007, p357). Other authors however, do draw clear distinctions between models of conceptual change by their speed. Gilbert and Watts (1983, pp. 8891) proposed two models of conceptual change: a stepped change model involving incremental changes in concepts and a 'catastrophe' model, involving a 'catastrophic change' to a conception that the authors argue, 'allows for that rapid change of conception which is called the 'Ah, ha' experience.' A similar model is Thornton 's (1997, pp. 247-249) contrast between 'extended conceptual transition' and 'punctuated conceptual evolution... an essentially instantaneous switch,' though he argues there is little evidence to support the existence of such conceptual discontinuities. Conceptual change may be considered as sudden in the ontological categorisation model of conceptual change (Chi, 1997, p230), and is linked to the 'aha' phenomenon. Finally, Clement (2008, p68) distinguishes between accretionism and eurekaism and links insight with '...reorganization in the sense that a new system of relationships was created' and 'relatively sudden conceptual change' (Clement, 2008, p99).

Evidence from several researchers however, presents conceptual change as a largely gradual process. Nussbaum (1989, p538), for example, proposes evidence indicates learning shows gradual change: '.... the student maintains substantial elements of the old conception while gradually incorporating individual elements from the new one.' In their original paper on conceptual change, Posner and colleagues (1982, p223), claim that their construction of radical does not imply abruptness and argue that accommodation is rarely characterized by 'a flash of insight'. Vosniadou and Ioannides (1998, p1226) report the idea of a sudden shift in conceptual structure implied by early models of conceptual change 'has not...been supported by empirical evidence.'

Moreover, Vosniadou (2008, pxvi) argues that what are claimed to be radical conceptual changes are really the end product of a 'slow and gradual affair and not a dramatic gestalt type shift.' This preceding slow and gradual affair may be an incubation period (Smith, 1995). An insight that appears sudden may be the accumulation of gradual incremental steps in understanding (Nersessian, 1999, p14). The debate regarding the rate of conceptual change may to some degree depend to the density of observation of conceptual change. The use of a microgenetic research method, which has a high density of observations relative to the phenomenon being investigated (Siegler \& Crowley, 1991, p606), may help to provide a clearer picture of the rate of conceptual change. 
However, though conceptual change may generally be incremental, there is some evidence that sudden changes occur. Indeed, Vosniadou (2008, pxvi) does not rule out abrupt restructuring, instead it is argued that it 'does not appear to be the usual road to conceptual change.' Fisher and Moody (2002, p67) also make the case that 'a flash of insight, is the exception rather than the rule.' Learning may turn out to be a mix of many processes, of gradual accretion of knowledge and of 'false starts, relapses to intuitive conceptions and, occasionally, highly motivating and personally significant experiences of insight—when everything suddenly "clicks together"' (Lappi, 2012, p2). Sudden moments of conceptual restructuring have been neglected in the research to date, perhaps due to their comparative infrequency, and the high density of observation required to capture them. Moments of insight, though rare, may none-the-less be highly significant moments in a learner's experience and repay the significant difficulties of investigating their properties more closely.

It is possible to find some reports of rapid conceptual change in the science education literature. One kind of rapid conceptual change involves an alteration in the conceptualisation of a problem. Insight has been linked to a change in problem representation (Duncker, 1945; Weisberg, 1996, p164; Chronicle, MacGregor, \& Ormerod, 2004). Bing and Redish (2009, p13) describe how a group of students solving a problem became stuck in a particular frame (a particular representation of the problem) for 15 minutes before being able to shift their interpretation sufficiently to solve the problem. In Clement's (1989) example of the spring problem, discussed in detail below, the process of breaking away from a particular conceptualisation is argued to be a significant skill: 'In order to generate an analogy ... the subject must break away from the original problem context' (Clement, 1989, p350). An example of a rapid reconceptualisation of a problem is seen in Parnafes (2012). Natalie, a student studying the phases of the moon, has an insight following another student's elaboration of which part of the illuminated moon is visible: 'Natalie: Ah! One moment, (takes Rose's hand away from the representation) the moon doesn't really get larger and smaller, it's simply what we see. We see only the illuminated part' (Parnafes, 2012, p393).

Parnafes (2012, p393) describes this as an "Aha" moment, a moment of meaningful insight, and argues it follows a representational innovation: the addition of a straight line to a diagram enables the student to understand that the moon does not alter in size, only in illumination. A shift in perception of the diagram has caused a sudden leap in understanding, as is reported in problem restructuring of insight problems (Weisberg, 1995, p164). Another reported moment of insight again involves a change in understanding of a representation. In an unpublished Master's thesis, Schwaller (2011) describes the case of students studying velocity time graphs by using data loggers and their subsequent whiteboard presentations to their peers.

One particular "aha" moment, documented in Lenny's learning log, specifically addressed the "graph as a picture" misconception... Lenny wrote, "I had an 'AHA!' moment when he explained that even if a ball was bounced straight up and down, it would still have a graph shaped like [a picture of a bouncing ball] because the graph is only showing the distance traveled from the ground, not the motion of the ball." (Schwaller, 2011, p29)

The student's conception of the velocity-time graph changes from a picture that directly represents reality to a more abstract representation: the shape of the line on a velocity time graph is not the shape of the physical motion. Schwaller $(2011, \mathrm{p} 20)$ reports: 'At times during the presentations, some students would spontaneously blurt 
out that they "got it."' Though there is some ambiguity in how "Aha" moments are defined, 28 are reported from 48 students in the course of one lab session (Schwaller, 2011, p26). The majority of these "Aha" moments (18) came during the presentations sections. The frequency with which students experience insight is an area that requires further research. The next section will consider moments of insight that result from the sudden formation of conceptual links.

\subsubsection{Insight in science education research: insight as the development of awareness of conceptual relationships}

A study of the neural activity of people solving insight problems has concluded that many insights involve the 'recognition of new connections across existing knowledge' (Jung-Beeman et al., 2004, p506) a view echoed by other researchers (Wren et al., 2004, p390; Bowden et al., 2005, p324; Koestler, 1964, p35). Developing connections features in Sternberg and Davidson's $(1983, \mathrm{p} 54)$ model of insight which involves: 'combining...isolated pieces of information into a unified whole' and 'relating newly acquired information to information acquired in the past.' These processes are similar to the conceptual integration proposed in Ausubel's (2000, p8) theory of meaningful learning and explain how insights may result in learning. As has been suggested in defining the concept of insight, the extent of the novel relationships developed in an insight may range from relatively small-scale connections (such as the link between a practical situation and a memory of holiday in Chin \& Brown, 2000, p186, below) or a more complex understanding of a network of relationships (see Clement, 1989, below).

In the example below, a group of students had been set the problem of separating a salt-sand mixture and had tried various approaches with no success. One of the students, Mary, describes how she recalled seeing a film of salt on some rocks during a visit to the seaside:

...finally it dawned on me, I was like woh! [...] you know, the ocean's moving you know. It's warm, the sun's on it. You know, maybe that's how it got there. And then it just clicked at me. I was like wow! (Chin \& Brown, 2000, p186)

The authors argue that the novel connection lead to the insight (Chin \& Brown, $2000, \mathrm{p} 186)$. In this case, as in the case of the spring problem described below, several ideas were tried before the solution was hit upon; insight is rarely completely spontaneous (Sadler-Smith, 2008, pp. 70-72; Sinclair, 2010, p380). Singh (2002, p1103) has argued that experts can solve problems quickly due to an ability to perform rapid memory searches to find a suitable connection for the problem in memory. In an article outlining the use of news articles to enhance learning, Singh claims to have observed 'several visible "aha" moments' which he associates with the formation of novels connections between pervious learning and information in the texts (Singh, 2011, pp. 482-483).

A particularly complex sub-set of the category of insights as perception-of connections is the case of insight via analogy formation. Analogies are defined as an 'overlap in relationships but not objects' (Gentner, 1983, p161) between domains and imply a significantly greater depth of similarity, namely structural likeness, than would be expected in a simpler connection. It has been argued that '[c]omparison processes foster insight' (Gentner \& Markman, 1997, p54) and so the development of links between a novel situation and a well understood base domain can be seen as bringing 
about insight (a well known example, is the analogy between the radiation problem and attack dispersion story found in Gick and Holyoak (1980)). The first step in the process of forming analogies is perceiving a significant similarity in structure between two domains (Gentner, 1983; Gentner \& Markman, 1997). Clement (1988) claims that students can form spontaneous analogies when they grasp similarities in the underlying structures of situations and Brock (2006) argues that insight is the result of the perception of a similar meta-structure between two domains. The observation that experts are better at being able to understand shared underlying abstractions than novices, who focus on surface details, may partly explain the connection between expertise and insight (Chi, Feltovich \& Glaser, 1981).

An extended discussion of the role of analogy in coming to understand a scientific problem is found in Clement's (1989, pp. 350-365) discussion of the spring problem shown in figure 4 . Clement set ten professors and graduate students the following problem: a weight is hung on a spring and its extension noted, the spring is then replaced with a different spring, which is made of the same material, has the same number of coils but their diameter is twice that of the original spring. The participants were asked to predict whether the second spring would stretch more, less or the same amount as the original spring and to justify their reasoning.

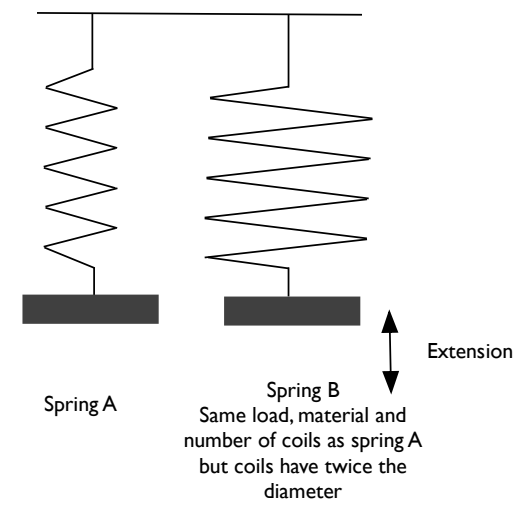

Figure 4: The spring problem in Clement (1989, p350).

One student attempting the problem is described as making several attempts to create different problem representations, most of which were unsuccessful: over forty minutes a rod, zigzag and other analogies were tried (Clement, 1989, p366). Following these attempts, a moment of 'insight' occurred when the student imagined a hexagonal coil which triggered a 'flood' of ideas that 'arrive[d] in a rush, as if they are outside of his control' (Clement, 1989, p365). This description is key to the categorization of this moment as an insight: though there has clearly been explicit cognition abut the problem, the final solution is reported as arriving suddenly and with little conscious control. The idea that torsion, as well as bending, will contribute to the extension of the spring, appeared 'fairly quickly, with little warning' (Clement, 1989, p358), within 80 seconds of the proposal of the hexagonal coil (Clement, 1989, p366). Clement reports these moments as being connected to emotional reactions and the student displayed 'some emphatic "aha" expressions with a raised tone of voice' (Clement, 1989, p359).

In analyzing the moment of insight in greater detail Clement argues there has been a reorganization of the student's mental model from one in which bending alone is relevant to the extension, to one which also includes torsion. The change is deliberately not described as 'revolutionary' as the bending model is not entirely replaced by a torsional model (Clement, 1989, p366). The insight, though rapid, is described as 'not 
instantaneous'; it occurred over a four minute period which leads Clement to believe that the processes involved might be 'unpackable' into subprocesses (Clement, 1989, p366). The insight is instead described as 'fairly sudden' rather than a 'bolt from the blue' and is therefore not a 'true Eureka event' (Clement, 1989, p366). Clement argues further that there are no extraordinary processes leading up to the insight and the student's thoughts follow a 'coherent story' throughout the process (Clement, 1989, p368).

Another example of insight as analogy formation is described by Nikitina and Mansilla (2003, pp. 10-11) who report a student who realized that 'magnetic waves' and the concept of flux in his mathematics class were 'the same understanding but at different angles.' It could be argued that the process of insight occurring in this case is due to the perception of a connection between a novel and a familiar concept. An extreme example of insight as the perception of connections may be the moment when seemingly different situations, are suddenly seen as being structurally similar (see for example Fuller's (1993) description of insight in statics above); Clement (1988, p573) describes this kind of simplification as the generation of a formal principle, a single abstract idea underlying multiple situations. The unification of diverse situations via a similarity in underlying structure (for example, the pendulum, mass on a spring and bobbing float are unified by simple harmonic motion) is seen as an important process in scientific understanding (Shive \& Weber, 1982, pxii; Kroes, 1989). The sparse reports in the science education literature make it difficult to build a detailed model of insight; the development of a larger catalogue of such moments is a necessary step to better understanding the process. The next section, by discussing the conditions that favour insight, may shed light on the apparently low incidence of insight in science classrooms.

\subsection{Conditions that promote insight}

Pasteur claimed that 'chance favours the prepared mind' (Rees, 2015, p13); this section will examine the conditions that promote or hinder the sudden realisations to which Pasteur was alluding. Insights may occur after periods of both conscious and nonconscious processing, though in both cases the ultimate understanding arrives without conscious control. It has been observed that, after attempting a problem that is not immediately solvable, if time is spent engaged in an unrelated activity, an insightful solution may occur (Smith, 1995, p241), a process known as incubation. One anonymous scientist argues for the necessity of taking a break from conscious thought: 'You have to do 6 months of very hard work first and get all the components bumping around in your head, and then you have to be idle for a couple of weeks, and then-ping-it suddenly falls into place' (Respondent D quoted in Csikszentmihalyi \& Sawyer, 1995, p350). There appear to be a variety of types of incubation, depending on the task, however a meta-analysis of studies of insight problem solving revealed: '[w]hen attempting to solve creative problems that require a wide search of knowledge, individuals benefit from an incubation period' (Sio \& Ormerod, 2009, p109).

If incubation time may promote the occurrence of insight, fixation may hinder insightful solutions. Fixation refers to 'an inappropriate adherence to an approach to solving a problem' (Smith, 1995, p235). For example, researchers have reported that students' inappropriate reliance on one rote learned principle (Le Chatelier's principle) led to difficulty in problem solving (Furió et al., 2000). In another example, commitment to an interpretation of a problem caused students to become 'stuck' in a particular frame of reasoning, leading to a failure to detect an error in their thinking (Bing \& Reddish, 2009 , p13). Encouraging students to be aware of their own framing of problems, and to practice developing alternative conceptualisations, may lead to more insightful problem solving. 
Certain kinds of problems seem to be particularly likely to cause the sudden jump in understanding described above, these are called 'insight problems' (Weisberg, 1995; Chronicle, MacGregor, \& Ormerod, 2004). Weisberg (1995, p164) proposed two criteria for an insight problem: a) there must be discontinuity, that is the solver cannot proceed directly to the solution without a switch of approach and b) there must be restructuring during which the solver's representation of the problem changes. Physics problems have been categorised into two groups: systematic problems, which can solved by consistent application of known procedures, and insight problems, which are resistant to algorithmic solution (Maloney, 2011, p5). Researchers in mathematics education have used a similar distinction, describing examination questions as either routine: 'students... execute a rehearsed procedure consisting of a limited number of steps,' or non-routine (Berry et al., 1999, p105). Designers of assessments might give consideration to the balance between routine and insight problems and the different skills they require of students. In general, a greater understanding of those conditions that foster insight in students is an area that requires further research.

\subsection{Productiveness of insight}

Insight, defined as a sudden explicit awareness of novel relations, is perhaps assumed to be an instance in which understanding converges on the canonical models of science. However, no such implication is intended and therefore a category of 'false' insights exists. Irvine (2015, p226) describes 'false aha' moments which 'seem like a genuine insight' but 'fail the verification process.' Categorising an insight as 'false' is problematic but consider the case of Jim Carter, described in Margaret Wertheim's (2011, p157) account of outsider physics: 'As he was falling asleep, he was stirred by a "delicious little dream" and suddenly the answer to the puzzle of nuclear structure crystallized in his mind.' Carter's theory of toroidal subatomic particles, cyclons, displays some coherence, yet conflicts with accepted scientific models and so might be thought of as a 'false' insight. It is has not been possible to find similar reports of students' 'false' insights in science yet it seems plausible moments of sudden awareness of connections that fail to match canonical scientific models occur. Researchers report that the 'sense of understanding' that may accompany insights is 'highly fallible' and '[p]eople often overestimate the detail, coherence, and depth of their understanding' (Ylikoski, 2009, p104). Just as with intuition, insight can be both support and hinder students' attempts to construct their own understandings of science. Whilst insights are often a desirable aspect of the work of scientists, there is no evidence, other than their speed, to consider insights as a necessary part of most students' problem solving experience in the classroom, they may however be of use to teachers in assessment. Davidson \& Sternberg, (1984, p55) have linked an ability to solve insight problems with giftedness and suggest insight problems may be used to identify gifted students without the confounding variable of prior learning.

\subsection{Strategies to support productive insights in the classroom}

There is disagreement about whether people can be trained to experience moments of insight more frequently. Dow and Mayer (2004, p397) have suggested that training for insight has little effect; the strategies required to solve insight problems are unique to their context and therefore not transferable. However, other investigators claim insight skills may be improved through training (Davidson \& Sternberg, 1984, p64; Kershaw \& Ohlsson, 2001) and even sleep may facilitate insightfulness (Wagner et al., 2004). In this section I shall proposes strategies that may maximise the possibility of students experiencing insight in the science classroom. 
The apparent sporadic nature of insightful moments in the classroom may be an effect of the kind of problems set in schools: questions routinely only involve a search for the right information or formula (Levi, 2012, p12). Insight problem solving can be encouraged by setting problems that don't have routine solution paths (Levi, 2012, p2). DeHaan (2009) advises educators to encourage students to try creative routes to problem solving rather than sticking to formulaic heuristics. Several books of physics problems that require non-routine solution methods are available (For example: Jargodzki \& Potter, 2001; Jargodzki \& Potter, 2004; Walker, 2008; Epstein, 2009). This is not to argue that drill like practice of routine questions has no place, it is necessary for becoming familiar with a novel procedure. However, such practice should not lead to the complete exclusion of open-ended problems, which require insight, synthesis and creative leaps (Felder \& Silverman, 1988, p68). Given the relationship between incubation periods and insights, it is worrying that the science curriculum in the United Kingdom has been described as 'overly-full and fact laden' (Royal Society, 2008, p180), and students report being rushed through content (Osborne \& Collins, 2000, p25). It has been suggested open-ended tasks, such as building up portfolios of work over extended periods, will 'allow time for the incubation of ideas' (Flick, 1993, p5) and may foster insight. Increased wait times may enable more students to reach moments of insight; teachers rarely allow long pauses after asking a complex question (Mujis \& Reynolds, 2010, p59). Little research exists on the frequency and causes of insightful moments in science education. It is hoped that by raising awareness of the process educators will be more receptive to opportunities that allow moments of insight to occur.

\subsection{The need for further research into tacit knowledge in science education}

Tacit knowledge is a challenging topic to investigate but it is hoped that the link between the tacit and the conscious that exists in intuition and insight will provide a route to understanding the concept. Due to their rapid and, at least partially, nonconscious nature, intuition and insight have been neglected in science education research (Bastick, 1982, pp. 10-12). In 1992, Fensham and Marton (p114) argued that researchers and curriculum developers in science education had largely ignored intuition and it was a rare teacher who recognised and nurtured intuition in their students (Fensham \& Marton, 1992, p120); little seems to have changed since then. Studies of tacit processes however, have made great progress (Kahneman, 2011) and have lead to an enriched understanding of cognition. It is time for science education to devote time and effort to developing a model of how tacit knowledge affects learning (Taber, 2014). Though this article has suggested conceptualisations of the processes of intuition and insight, there are few empirical studies of the processes in science education. It is well accepted that students sometimes use intuitive concepts but there is a weaker understanding of how such intuitions develop and when and why they are used. Very few reports of students' scientific insights exist and so the nature and causes of these powerful moments has been neglected. Listed below are some of the unanswered questions concerning insight and intuition raised by this paper:

a) Do some individuals have intuitions that are more aligned with the accepted models of science? Are these individuals 'better' scientists?

b) What are the contingencies that influence when intuitions are accessed in preference to more explicit knowledge?

c) Can intuitions be 'taught' through engagement with practical work and computer simulations?

d) How frequent are moments of insight in science learning and what hinders or promotes their occurrence?

e) Is there any advantage to encouraging students to experience moments of insight in solving problems compared to routine approaches? 
More empirical studies of intuition and insight are required to answer these questions. It is beyond the scope of this paper to go into detail of the methods might be used to research tacit knowledge (Wagner \& Sternberg, 1985), intuition (Sinclair, 2014) and insight (Chu \& MacGregor, 2011), but for the interested researcher, techniques to study these concepts exist and have been used in various contexts. It may be that tacit knowledge is more influential on conscious thought in some contexts than others, however at this early stage in the research programme, it would be useful to see studies of tacit knowledge across a broad range of content areas within science education. Students and experts know more about science than they can directly express in words. In order to develop the fullest model of scientific understanding possible, researchers should begin to focus attention on tacit components of knowledge in science education. .

Acknowledgement

I would like to thank Keith Taber for his support and advice during the development of this article. I am also grateful to the anonymous reviewers for their constructive feedback.

\subsection{References}

Akinci, C., \& Sadler-Smith, E. (2013). Assessing individual differences in experiential (intuitive) and rational (analytical) cognitive styles. International Journal of Selection and Assessment, 21(2), 211-221.

Allinson, C. W., \& Hayes, J. (1996). The cognitive style index: A measure of intuitionanalysis for organizational research. Journal of Management studies, 33(1), 119-135.

Andersson, B. (1986). The experiential gestalt of causation: A common core to pupils' preconceptions in science. European Journal of Science Education, 8(2), 155-171.

Atkinson, T., \& Claxton, G. (Eds.) (2000). The Intuitive Practitioner: on the value of not always knowing what one is doing. Buckingham: Open University Press.

Ausubel, D. (2000). The Acquisition and Retention of Knowledge. Dordrecht: Kluwer Academic Publishers.

Baldwin, R. (1997). Merging a deep intuitive ecological understanding with conservation biology: An AEI approach. The Trumpeter. 14(2) Available at:

http://trumpeter.athabascau.ca/index.php/trumpet/article/view/199/266 [Accessed $6^{\text {th }}$ February 2015]

Bastick , T. (1982). Intuition. How we Think and Act. Chichester: John Wiley and Sons.

Baylor, A. L. (2001). A U-shaped model for the development of intuition by level of expertise. New Ideas in Psychology, 19(3), 237-244.

Berry, D. C., \& Broadbent, D. E. (1988). Interactive tasks and the implicit-explicit distinction. British journal of Psychology, 79(2), 251-272.

Berry, J., Johnson, P., Maull, W. \& Monaghan, J. (1999). Routine Questions and Examination Performance. In: O. Zaslavsky (Ed.), Proceedings of the $23^{\text {rd }}$ Conference of the International Group for the Psychology of Mathematics Education (PME23), pp. 105112, 1999. Technion, Haifa, Israel. Available at: http://eric.ed.gov/?id=ED436403 
[Accessed 6 ${ }^{\text {th }}$ February 2015]

Bing, T. J., \& Redish, E. F. (2009). Analyzing problem solving using math in physics: Epistemological framing via warrants. Physical Review Special Topics-Physics Education Research, 5(2), 020108.

Black, J. B. (2010). An embodied/grounded cognition perspective on educational technology. In I. Saleh (Ed.), New science of learning: Cognition computers and collaboration in education (pp. 45-52). New York: Springer Publishing.

Bolte, A., \& Goschke, T. (2005). On the speed of intuition: Intuitive judgments of semantic coherence under different response deadlines. Memory \& Cognition, 33(7), 1248-1255.

Bowden, E. M., Jung-Beeman, M., Fleck, J., \& Kounios, J. (2005). New approaches to demystifying insight. Trends in Cognitive Sciences, 9(7), 322-328.

Bransford, J., Brown, A,L. \& Cocking, R. (Eds.) (2000). How people learn: Brain, mind, experience, and school. Washington, DC: National Academies Press.

Brock, R. (2006). Intuition and integration: insights from intuitive students. Unpublished M.Phil. thesis, University of Cambridge. Available at:

http://people.ds.cam.ac.uk/kst24/researchstudents/brock\%202006\%20mphil\%20intu ition\%20\&\%20integration.pdf [Accessed 6 ${ }^{\text {th }}$ February 2015]

Bruner, J. S. (1977). The process of education. Cambridge, MA: Harvard University Press.

Campanario, J. M. (1998). Using counterintuitive problems in teaching physics. The Physics Teacher, 36, 439-441.

Caravita, S., \& Halldén, O. (1994). Re-framing the problem of conceptual change. Learning and instruction, 4(1), 89-111.

Catlow, R. (2013). Inorganic materials: Intuition weaved into computation. Nature chemistry, 5(8), 648-649.

Chabris, C., \& Simons, D. (2011). The invisible gorilla: and other ways our intuitions deceive us. New York, NY: Broadway Books.

Champagne, A. B., Gunstone, R. F., \& Klopfer, L. E. (1985). Instructional consequences of students' knowledge about physical phenomena. In L. H. T. West \& A. L. Pines (Eds.), Cognitive structure and conceptual change (pp. 61-68). New York, NY: Academic Press.

Chi, M. T. H. (1997). Creativity: Shifting across ontological categories flexibly. In B. T. Ward \& S. M. Smith (Eds.), Creative thought: An investigation of conceptual structures and processes (pp. 209-234). Washington, DC: American Psychological Association.

Chi, M. T., Feltovich, P. J., \& Glaser, R. (1981). Categorization and representation of physics problems by experts and novices. Cognitive science, 5(2), 121-152.

Chi, M. T., \& Slotta, J. D. (1993). The ontological coherence of intuitive physics. Cognition and Instruction, 10(2-3), 249-260.

Chin, C., \& Brown, D. E. (2000). Learning deeply in science: An analysis and reintegration 
of deep approaches in two case studies of grade 8 students. Research in Science Education, 30(2), 173-197.

Chow, T. L. (2008). Gravity, Black Holes, and the Very Early Universe. Gravity, Black Holes, and the Very Early Universe. New York, NY: Springer.

Chronicle, E. P., MacGregor, J. N., \& Ormerod, T. C. (2004). What Makes an Insight Problem? The Roles of Heuristics, Goal Conception, and Solution Recoding in Knowledge-Lean Problems. Journal of Experimental Psychology: Learning, Memory, and Cognition, 30(1), 14-27.

Chu, Y. \& MacGregor, J. N. (2011). Human performance on insight problem solving: A review. The Journal of Problem Solving, 3(2), 119-150.

Claxton, G. (1993). Minitheories: a preliminary model for learning science. In P. J. Black \& A. M. Lucas (Eds.), Children 's Informal Ideas in Science (pp. 45-61). London: Routledge.

Claxton, G. (1998). Investigating human Intuition: Knowing Without Knowing Why. The Psychologist. 11(5), 217-220.

Clement, J. (1988). Observed methods for generating analogies in scientific problem solving. Cognitive Science, 12(4), 563-586

Clement, J. (1989). Learning via model construction and criticism. In G. Glover, R. Romming, \& C. Reynolds (Eds.), Handbook of creativity: Assessment, theory and research (pp. 341-381). New York, NY: Plenum.

Clement, J. (1991). Nonformal reasoning in experts and science students; the use of analogies, extreme cases and physical intuition. In J. Voss, D. Perkins \& J. Segal (Eds.), Informal Reasoning in Science Instruction (pp. 345-362). Hillsdale, NJ: Lawrence Erlbaum Associates

Clement, J. (1998). Expert novice similarities and instruction using analogies. International Journal of Science Education, 20(10), 1271-1286.

Clement, J. J. (2008). Creative model construction in scientists and students. Dordecht: Springer.

Clement, J., Brown, D. E., \& Zietsman, A. (1989). Not all preconceptions are misconceptions: finding 'anchoring conceptions' for grounding instruction on students' intuitions. International Journal of Science Education, 11(5), 554-565.

Cloninger, K. (2006). Making intuition practical: A new theoretical framework for education. Curriculum and Teaching Dialogue, 8(1), 15-28.

Cohen, R., \& Yarden, A. (2009). Experienced junior-high-school teachers' PCK in light of a curriculum change: "The cell is to be studied longitudinally" Research in Science Education, 39(1), 131-155.

Csikszentmihalyi, M., \& Sawyer, K. (1995). Creative insight: The social dimension of a solitary moment In R. J. Sternberg \& J. E. Davidson (Eds.), The nature of insight (pp. 329363). Cambridge, MA: MIT Press.

Dane, E., \& Pratt, M. G. (2007). Exploring Intuition and Its Role in Managerial Decision 
Making. Academy of Management Review, 32(1), 33-54.

Danielak, B. A., Gupta, A., \& Elby, A. (2010). The marginalized identities of sense-makers: Reframing engineering student retention. In Frontiers in Education Conference (FIE), 2010 IEEE. Available at: http://arxiv.org/pdf/1003.4655.pdf [Accessed 6th February 2015]

Davidson, J.E. \& Sternberg, R.J. (1984). The role of insight in intellectual giftedness. Gifted Child Quarterly, 28(2), 58-64.

DeHaan, R. L. (2009). Teaching creativity and inventive problem solving in science. CBELife Sciences Education, 8(3), 172-181.

De Kleer, J., \& Brown, J. S. (1984). A qualitative physics based on confluences. Artificial intelligence, 24(1), 7-83.

Dembo, M. H., \& Howard, K. (2007). Advice about the Use of Learning Styles: A Major Myth in Education. Journal of College Reading and Learning, 37(2), 101-109.

diSessa, A. A. (1985). Learning about knowing. In E. L. Klein (Ed.), New directions for child development: Vol. 28 Children and computers (pp. 97-124). San Francisco, CA: Jossey-Bass.

disessa, A. A. (1986). Artificial worlds and real experience. Instructional Science, 14(3), 207-227.

diSessa, A. A. (1993). Toward an epistemology of physics. Cognition and Instruction, 10(2-3), 105-225.

diSessa, A. A. (2000). Changing minds: Computers, learning, and literacy. Cambridge, MA: MIT Press.

diSessa, A. A. (2002). Why "conceptual ecology" is a good idea. In M. Limon \& L. Mason (Eds.), Reconsidering conceptual change: Issues in theory and practice (pp. 29-60). Dortrecht: Kluwer.

Dominowski, R. L., \& Dallob, P. (1995). Insight and problem solving. In R.J. Sternberg \& J.E. Davidson (Eds.), The nature of insight (pp. 33-62). Cambridge, MA: The MIT Press.

Dove, G. O. (2011). On the need for embodied and dis-embodied cognition. Frontiers in Cognition, 1, 1-13, Article 242.

Dow, G. T., \& Mayer, R. E. (2004). Teaching students to solve insight problems: Evidence for domain specificity in creativity training. Creativity Research Journal, 16(4), 389-398.

Dresp-Langley, B. (2012). Why the Brain Knows More than We Do: Non-Conscious Representations and Their Role in the Construction of Conscious Experience. Brain Sciences, 2(1), 1-21.

Dreyfus, S. E. \& Dreyfus, H. L. (1980). A five-stage model of the mental activities involved in directed skill acquisition. Technical Report Operations Research Centre. Berkley, CA: University of California.

Driver, R., Guesne, E., \& Tiberghien, A. (1985). Children's ideas and the learning of science. 
Buckingham: Open University Press.

Driver, R., Squires, A., Rushworth, P., \& Wood-Robinson, V. (1994). Making sense of secondary science. London: Routledge.

Duit R. (1994). The constructivist view in science education: what it has to offer and what should not be expected from it. Paper presented at the International Conference: Science and Mathematics for the $21^{\text {st }}$ Century: Towards Innovatory Approaches, Concepcion, Chile, $2^{\text {th }}$ September-1 ${ }^{\text {st }}$ October, 1994. Available at:

http://www.cienciamao.usp.br/dados/ienci/ theconstructivistviewins.artigocompleto. pdf [Accessed 6th February 2015]

Duit, R., \& Treagust, D. F. (2003). Conceptual change: a powerful framework for improving science teaching and learning. International Journal of Science Education, 25(6), 671-688.

Dunbar, K. (1995). How scientists really reason: Scientific reasoning in real-world laboratories. In R. J. Sternberg \& J. E. Davidson (Eds.), The nature of insight (pp. 365395). Cambridge, MA: MIT Press.

Duncker, K. (1945). On problem solving. Psychological Monographs, 58(5), 270, i-113.

Dyson, F. J. (1972). Missed opportunities. Bulletin of the American Mathematical Society, 78(5), 635-652.

Entwistle, N., \& Nisbet, J. (2013). The nature and experience of academic understanding. The Psychology of Education, 37(1), 5-14.

Epstein, L. C. (2009). Thinking Physics: Understandable Practical Reality. San Francisco, CA: Insight Press

Evans, T. (2011). The Art and Science of Light Bulb Moments. Winchester: O-Books.

Fensham, P.J. \& Marton, F. (1992). What has Happened to Intuition in Science Education? Research in Science Education. 22(1), 114-122.

Felder, R. M., Felder, G. N., \& Dietz, E. J. (2002). The effects of personality type on engineering student performance and attitudes. Journal of Engineering Education, 91(1), 3-17.

Felder, R. M., \& Silverman, L. K. (1988). Learning and teaching styles in engineering education. Engineering Education, 78(7), 674-681.

Feyerabend, P. (1970). Against Method: Outline of an Anarchistic Theory of Knowledge. In M. Radner \& W.Winokur (Eds.), Minnesota Studies in the Philosophy of Science (pp. 17130). Volume IV: Theories \& Methods of Physics and Psychology. Minneapolis: University of Minnesota.

Feynman, R. (1985). Surely you're joking Mr Feynman. New York, NY: Bantam Books.

Feynman, R. P. (2013). Laws and Intuition. In R.P. Feynman, M.A. Gottlieb, M. A. \& R. Leighton (Eds.), Feynman's Tips on Physics: Reflections, Advice, Insights, Practice (pp. 6189). New York, NY: Basic Books. 
Fischbein, E. (1987). Intuition in science and mathematics. Dordrecht: Reidel.

Fischbein, E., Tirosh, D., Stavy, R., \& Oster, A. (1990). The autonomy of mental models. For the Learning of Mathematics, 10(1), 23-30.

Fisher, K., \& Moody, D. (2002). Student misconceptions in biology. In K.M. Fisher, J.H. Wandersee \& D.E. Moody (Eds.), Mapping biology knowledge (pp. 55-75). Dordecht: Springer.

Flick, L. B. (1993). The meanings of hands-on science. Journal of Science Teacher Education, 4(1), 1-8.

Forbus, K. D. (1984). Qualitative process theory. Artificial intelligence, 24(1), 85-168.

Fredrickson, B.L. (2001). The role of positive emotions in positive psychology: The broaden-and-build theory of positive emotions. American Psychologist, 56(3), 218-226.

Fuller, R.G. (1993). Millikan Lecture, 1992. Hypermedia and the knowing of physics: standing upon the shoulders of giants. American Journal of Physics, 61(4), 300-304.

Furió, C., Calatayud, M. L., Barcenas, S. L., \& Padilla, O. M. (2000). Functional fixedness and functional reduction as common sense reasonings in chemical equilibrium and in geometry and polarity of molecules. Science Education, 84(5), 545-565.

Gentner, D. (1983). Structure-mapping: A Theoretical Framework for Analogy. Cognitive Science, 7(2), 155-170.

Gentner , D. \& Markman , A. (1997). Structure mapping in analogy and similarity. American Psychologist. 52(1), 45-56.

Gick, M. L., \& Holyoak, K. J. (1980). Analogical problem solving. Cognitive Psychology, 12(3), 306-355.

Gilbert, J. K., \& Watts, D. M. (1983). Concepts, misconceptions and alternative conceptions: changing perspectives in science education. Studies in Science Education, 10(1), 61-98.

Gladwell, M. (2005). Blink: The power of thinking without thinking. New York, NY: Little, Brown.

Glöckner, A., \& Ebert, I. D. (2011). Legal intuition and expertise. In M. Sinclair (Ed.), Handbook of intuition research (pp. 157-167). Cheltenham: Edward Elgar Publishing.

Glöckner, A. \& Witteman, C. (2010). Foundations for Tracing Intuition. New York, NY: Psychology Press, New York.

Goldberg, P. (1985). The Intuitive Edge: Understanding and Developing Intuition. Wellingborough: Turnstone.

Goldberg, R. F., \& Thompson-Schill, S. L. (2009). Developmental "roots" in mature biological knowledge. Psychological Science, 20(4), 480-487. 
Gruber, H. E. (1995). Insight and affect in the history of science. In R. J. Sternberg \& J. E. Davidson (Eds.), The nature of insight (pp. 397-431). Cambridge, MA: MIT Press.

Gupta, A., \& Elby, A. (2011). Beyond Epistemological Deficits: Dynamic explanations of engineering students' difficulties with mathematical sense-making. International Journal of Science Education, 33(18), 2463-2488.

Gupta, A., Elby, A., \& Conlin, L. D. (2014). How substance-based ontologies for gravity can be productive: A case study. Physical Review Special Topics-Physics Education Research, 10(1), 010113.

Hall, K. H. (2002). Reviewing intuitive decision-making and uncertainty: the implications for medical education. Medical Education, 36(3), 216-224.

Halpern,D. F. (2005). That Aha Moment When Understanding Happens-That Is Why I Teach In T.A. Benson, C. Burke, A. Amstadter, R. Siney, V. Hevern, B. Beins, \& W. Buskist, (Eds.), Teaching psychology in autobiography: Perspectives from exemplary psychology teachers (pp. 141-146). Society for the Teaching of Psychology. E-Book available from the Society for the Teaching of Psychology Web site: http://teachpsych.org/ebooks/tia2005/index.php\#.UihJnGR4aEw [Accessed 6 ${ }^{\text {th }}$ February 2015]

Hammer, D. (1989). Two approaches to learning physics. The Physics Teacher, 27(9), 664-670.

Hammer, D. (1994). Epistemological beliefs in introductory physics. Cognition and Instruction, 12(2), 151-183.

Hammer, D., \& Elby, A. (2003). Tapping epistemological resources for learning physics. The Journal of the Learning Sciences, 12(1), 53-90.

Hammond, K.R. (1980). The integration of research in judgment and decision theory. (Report \#226). Boulder: University of Colorado, Center for Research on Judgment and Policy.

Hodgkinson, G. P. \& Sadler-Smith, E. (2011). Investigating intuition: beyond self-report. In M. Sinclair (Ed.), Handbook of intuition research, (pp. 52-66). Cheltenham: Edward Elgar Publishing Ltd.

Hodgkinson, G. P., Sadler-Smith, E., Sinclair, M., \& Ashkanasy, N. M. (2009). More than meets the eye? Intuition and analysis revisited. Personality and Individual Differences, 47(4), 342-346.

Hodson, D. (1993). Re-thinking old ways: Towards a more critical approach to practical work in school science. Studies in Science Education, 22(1), 85-142.

Hofer, B. K. (2001). Personal epistemology research: Implications for learning and teaching. Educational Psychology Review, 13(4), 353-383.

Hofer, B. K., \& Pintrich, P. R. (1997). The development of epistemological theories: Beliefs about knowledge and knowing and their relation to learning. Review of Educational Research, 67(1), 88-140. 
Hogarth, R. (2001). Educating Intuition. Chicago, IL: The University of Chicago Press.

Howe, C., Devine, A., \& Taylor Tavares, J. (2013). Supporting Conceptual Change in School Science: A possible role for tacit understanding. International Journal of Science Education, 35(5), 864-883.

Irvine, W.B. (2015). Aha!: The moments of insight that shape our world. Oxford: Oxford University Press.

Jansen, V. A. (2001). The dynamics of two diffusively coupled predator-prey populations. Theoretical Population Biology, 59(2), 119-131.

Jargocki, C. P. (1983). More science braintwisters and paradoxes. New York, NY: Van Nostrand Reinhold Company.

Jargodzki, C., \& Potter, F. (2002). Mad about physics: braintwisters, paradoxes, and curiosities. New York, NY: Wiley.

Jargodzki, C. \& Potter, F. (2004). Mad about modern physics: braintwisters, paradoxes, and curiosities. New York, NY: Wiley.

Jeng, M. (2006). A selected history of expectation bias in physics. American Journal of Physics, 74(7), 578-583.

Jung, C.G. (1971). Psychological Types. Princeton, NJ: Princeton University Press.

Jung-Beeman, M. J., Bowden, E. M., Haberman, J., Frymiare, J. L., Arambel-

Liu, S., Greenblatt, R., Reber, P. J., \& Kounios, J. (2004). Neural activity

when people solve verbal problems with insight. Plos Biology, 2, 500-510.

Kahneman, D. (2003). A perspective on judgment and choice: mapping bounded rationality. American Psychologist, 58(9), 697-720.

Kahneman, D. (2011). Thinking, fast and slow. London: Penguin.

Kardash, C. M., \& Howell, K. L. (2000). Effects of epistemological beliefs and topicspecific beliefs on undergraduates' cognitive and strategic processing of dual-positional text. Journal of Educational Psychology. 92(3), 524-535.

Kelemen, D., Rottman, J. \& Seston, R. (2013). Professional physical scientists display tenacious teleological tendencies: Purpose-based reasoning as a cognitive default. Journal of Experimental Psychology. 142(4), 1074-1083.

Keller, A. (2000). Reminiscences on the discovery of chain folded single crystals. Polymer, 41(25), 8751-8754.

Kershaw, T. C., \& Ohlsson, S. (2001). Training for insight: The case of the nine-dot problem. In J.D. Moore \& K. Stennigs (Eds.), Proceedings of the 23rd Annual Conference of the Cognitive Science Society (pp. 489-493). Mahwah, NJ: Erlbaum.

Keserü, G. M., Soós, T., \& Kappe, C. O. (2014). Anthropogenic reaction parameters-the missing link between chemical intuition and the available chemical space. Chemical Society Reviews. 43(15), 5387-5399. 
Koestler, A. (1964). The Act of Creation. London: Hutchinson and Co.

Koshland Jr., D. E. (2007). The Cha-Cha-Cha theory of scientific discovery. Science, 317(5839), 761-762.

Kosso, P. (2002). The omniscienter: Beauty and scientific understanding. International Studies in the Philosophy of Science, 16(1), 39-48.

Kounios, J., \& Beeman, M. (2009). The Aha! Moment. The Cognitive Neuroscience of Insight. Current Directions in Psychological Science, 18(4), 210-216.

Kounios, J., Frymiare, J. L., Bowden, E. M., Fleck, J. I., Subramaniam, K., Parrish, T. B., \& Jung-Beeman, M. (2006). The prepared mind neural activity prior to problem presentation predicts subsequent solution by sudden insight. Psychological Science, 17(10), 882-890.

Kroes, P. (1989). Structural analogies between physical systems. The British journal for the philosophy of science, 40(2), 145-154.

Kuhn, T. S. (1993). Foreword. In P. Hoyningen-Huene, Reconstructing scientific revolutions: Thomas S. Kuhn's philosophy of science (pp. xi-xiii). Chicago: University of Chicago Press.

Kuiper, J. (1994). Student ideas of science concepts: alternative frameworks? International Journal of Science Education, 16(3), 279-292.

Lakoff, G., \& Johnson, M. (1980). Metaphors we live by. London: University of Chicago Press.

Lappi, O. (2012). Qualitative Quantitative and Experimental Concept Possession, Criteria for Identifying Conceptual Change in Science Education. Science \& Education, 22(6) 1347-1359.

Larkin, J., McDermott, J., Simon, D. P., \& Simon, H. A. (1980). Expert and novice performance in solving physics problems. Science, 208(4450), 1335-1342.

Laughlin , C. (1997). The Nature Of Intuition In R. Davis-Floyd \& P. Arvidson (Eds.), Intuition The Inside Story (pp. 19-38). London: Routledge.

Levi, M. (2012). Why Cats Land on Their Feet: And 76 Other Physical Paradoxes and Puzzles. Cambridge, MA: Princeton University Press

Lewicki, P., Hill, T., \& Czyzewska, M. (1992). Nonconscious acquisition of information. American Psychologist, 47(6), 796-801.

Lieberman, M. D. (2000). Intuition: A social cognitive neuroscience approach. Psychological Bulletin, 126(1), 109-137.

Lising, L., \& Elby, A. (2005). The impact of epistemology on learning: A case study from introductory physics. American Journal of Physics, 73(4), 372-382.

Loughran, J. (2006). Towards a better understanding of science teaching. Teaching Education, 17(2), 109-119. 
Mahon, B. Z., \& Caramazza, A. (2008). A critical look at the embodied cognition hypothesis and a new proposal for grounding conceptual content. Journal of PhysiologyParis, 102(1), 59-70.

Maloney, D. P. (2011). An overview of physics education research on problem solving. In C. Henderson \& K. A. Harper (Eds.), Reviews in PER: Getting Started in PER. 2(1). College Park, MD: American Association of Physics Teachers. [Available at: http://www.per-central.org/items/detail.cfm?ID=11457

[Accessed 6 ${ }^{\text {th }}$ February 2015]

Marton, F., Fensham, P. \& Chaiklin, S. (1994). A Nobel's Eye View of Scientific Intuition: Discussions with Nobel Prize-winners in Physics, Chemistry and Medicine (1970-86). International Journal of Science Education. 16(4) 457-473.

Mason, L., Boscolo, P., Tornatora, M. C., \& Ronconi, L. (2013). Besides knowledge: A cross-sectional study on the relations between epistemic beliefs, achievement goals, self-beliefs, and achievement in science. Instructional Science, 41(1), 49-79.

Mayer, R. E. (1995). The search for insight: Grappling with Gestalt psychology's unanswered questions In R.J. Sternberg \& J.E. Davidson (Eds.), The nature of insight (pp. 3-32). Cambridge, MA: The MIT Press.

McCloskey, M. (1983). Intuitive physics. Scientific American, 248(4), 114-122.

McCutcheon, H. H., \& Pincombe, J. (2001). Intuition: an important tool in the practice of nursing. Journal of Advanced Nursing, 35(3), 342-348.

McLaughlin, J. S. (2005). Classrooms without walls. Journal of College Science Teaching, 34(4), 5-6.

Merleau-Ponty, M. (1945/2005). Phenomenology of Perception (C.Smith, Trans.). London: Routledge.

Metcalfe, J. (1986). Premonitions of insight predict impending error. Journal of Experimental Psychology: Learning, Memory, and Cognition, 12(4), 623-634.

Metcalfe, J., \& Wiebe, D. (1987). Intuition in insight and noninsight problem solving. Memory and cognition, 15(3), 238-246.

Miller, G. A. (1962). Psychology: The science of mental life. New York, NY: Harper \& Row.

Miller, G. A. (1967). The psychology of communication: Seven essays. New York, NY: Basic Books.

Moore, W.S. (2002). Understanding Learning in a Postmodern World: Reconsidering the Perry Scheme of Ethical and Intellectual Development. In B.K. Hofer, \& P.R. Pintrich (Eds.), The Psychology of Beliefs About Knowledge and Knowing (pp. 17-36). Mahwah, NJ: Lawrence Erlbaum.

Muijs, D., \& Reynolds, D. (2010). Effective teaching: Evidence and practice. London: Sage Publishing.

Muis, K. R. (2004). Personal epistemology and mathematics: A critical review and synthesis of research. Review of Educational Research, 74(3), 317-377. 
Myers, D. G. (2004). Intuition: Its powers and perils. London: Yale University Press.

Nersessian, N. J. (1999). Model-based reasoning in conceptual change. In L. Magnani, N. Nersessian \& P. Thagard (Eds.), Model-Based Reasoning in Scientific Discovery (pp. 5-22). New York: Plenum

Nikitina, S., \& Mansilla, V. B. (2003). Three Strategies for Interdisciplinary Math and Science Teaching: A Case of the Illinois. Available at: http://www.dlsu.edu.ph/offices/avcaa/pdf/stategies-math-science-teaching.pdf [Accessed 6 ${ }^{\text {th }}$ February 2015]

Nisbett, R. E., \& Wilson, T. D. (1977). Telling more than we can know: Verbal reports on mental processes. Psychological review, 84(3), 231.

Nussbaum, J. (1989). Classroom conceptual change: philosophical perspectives. International Journal of Science Education, 11(5), 530-540.

O'Brien, T. P., Bernold, L. E., \& Akroyd, D. (1998). Myers-Briggs type indicator and academic achievement in engineering education. International Journal of Engineering Education, 14(5), 311-315.

Oliphant, M. (1972). Some Personal Recollections of Rutherford, the Man. Notes and Records of the Royal Society of London, 27(1), 7-23.

Osborne, J., \& Collins, S. (2000). Pupils' and parents' views of the school science curriculum. School Science Review, 82(298), 23-31.

Özdemir, G., \& Clark, D. B. (2007). An overview of conceptual change theories. Eurasia Journal of Mathematics, Science \& Technology Education, 3(4), 351-361.

Parnafes, O. (2012). Developing explanations and developing understanding: Students explain the phases of the Moon using visual representations. Cognition and Instruction, $30(4), 359-403$.

Perry, W. B. (1970). Forms of intellectual and ethical development in the college years: $A$ scheme. New York: Holt, Rinehart \& Winston.

Petitmengin-Peugeot, C. (1999). The intuitive experience. Journal of Consciousness Studies, 6(2-3), 43-77.

Planck, M. (1950) Scientific autobiography and other papers. London: Williams and Norgate.

Polanyi, M. (1962). Personal knowledge. Chicago, IL: University of Chicago Press.

Polanyi, M. (1966). The logic of tacit inference. Philosophy, 41(155), 1-18.

Polanyi, M. (1966/2009). The tacit dimension. Chicago, IL: University of Chicago Press.

Polanyi, M. (1967). The growth of science in society. Minerva, 5(4), 533-545.

Pomeroy, D. (1993). Implications of teachers' beliefs about the nature of science:

Comparison of the beliefs of scientists, secondary science teachers, and elementary 
teachers. Science education, 77(3), 261-278.

Popper, K.R. (1959). The Logic of Scientific Discovery. London: Hutchinson.

Posner, G. J., Strike, K. A., Hewson, P. W., \& Gertzog, W. A. (1982). Accommodation of a scientific conception: Toward a theory of conceptual change. Science education, 66(2), 211-227.

Preece, P. F. (1984). Intuitive science: Learned or triggered? European Journal of Science Education, 6(1), 7-10.

Pronin, E. (2009). The Introspection Illusion. In M. P. Zanna (Ed.), Advances in Experimental Social Psychology, (Vol. 14, pp. 1-67). San Diego, CA: Academic Press.

Qian, G., \& Alvermann, D. (1995). Role of epistemological beliefs and learned helplessness in secondary school students' learning science concepts from text. Journal of educational psychology, 87(2), 282-292.

Qian, G., \& Alvermann, D. (2000). Relationship between epistemological beliefs and conceptual change learning. Reading \& Writing Quarterly, 16(1), 59-74.

Ragan, M. A., \& Chan, C. X. (2013). Biological Intuition in Alignment-Free Methods: Response to Posada. Journal of molecular evolution, 77(1-2), 1-2.

Ramsland, K. M. (2012). Snap: Seizing Your Aha! Moments. Amherst, NY: Prometheus Books.

Reber, A. S. (1989). Implicit learning and tacit knowledge. Journal of Experimental Psychology: General, 118(3), 219-235.

Redish, E. F. (2003). Teaching physics with the physics suite. Hoboken, NJ: John Wiley \& Sons.

Redish, E. F. (2010). Introducing students to the culture of physics: Explicating elements of the hidden curriculum. arXiv preprint arXiv:1008.0578. Available at: http://arxiv.org/pdf/1008.0578v1.pdf [Accessed 6 ${ }^{\text {th }}$ February 2015]

Rees, A. R. (2015). The antibody molecule from antitoxins to therapeutic antibodies. Oxford: Oxford University Press.

Reif, F. (1987). Interpretation of scientific or mathematical concepts: Cognitive issues and instructional implications. Cognitive Science, 11(4), 395-416.

Reif, F. (2008). Applying cognitive science to education: thinking and learning in scientific and other complex domains. Cambridge, MA: MIT Press.

Reiner, M., \& Gilbert, J. (2000). Epistemological resources for thought experimentation in science learning. International Journal of Science Education, 22(5), 489-506.

Riener, C., Proffitt, D. R., \& Salthouse, T. (2005). A psychometric approach to intuitive physics. Psychonomic Bulletin \& Review, 12(4), 740-745.

Robert, M. (1990). Sex-typing of the water-level task: There is more than meets the eye. International Journal of Psychology, 25(2), 475-490. 
Rohrlich, F. (1996). The unreasonable effectiveness of physical intuition: success while ignoring objections. Foundations of Physics, 26(12), 1617-1626.

Royal Society (2008). Science and mathematics education, 14-19: A 'state of the nation' report on the participation and attainment of 14-19 year olds in science and mathematics in the UK, 1996-2007. Available from:

https://royalsociety.org/education/policy/state-of-nation/14-19/

[Accessed 6 ${ }^{\text {th }}$ February 2015]

Rule, D.C \& Bendixen, L.D. (2010). The integrative model of personal epistemology development: theoretical underpinnings and implications for education. In L. Bendixen \& B. Feucht (Eds.), Personal Epistemology in the Classroom: Theory, Research, and Implications for Practice (pp. 94-123). Cambridge: Cambridge University Press.

Russell, T. \& Munby, H. (1989). Science as a discipline, science as seen by students and teachers' professional knowledge. In R. Millar (Ed.), Doing Science: Images of Science in Science Education (pp. 107-125). Abingdon: Routledge.

Sadler-Smith, E. (2008). Inside intuition. Abingdon: Routledge.

Sadler-Smith, E., \& Burke, L. A. (2009). Fostering Intuition in Management Education Activities and Resources. Journal of Management Education, 33(2), 239-262.

Salk, J. (1983). Anatomy of reality: Merging of intuition and reason. New York, NY: Colombia University Press.

Schoenfeld, A. H. (1989). Exploration of students' mathematical beliefs and behavior. Journal for Research in Mathematics Education, 20(4), 338-355.

Schommer, M. (1990). Effects of beliefs about the nature of knowledge on comprehension. Journal of Educational Psychology, 82(3), 498.

Schooler, J. W., \& Dougal, S. (1999). The symbiosis of subjective and experimental approaches to intuition. Journal of Consciousness Studies, 6(2-3), 280-287.

Schwaller, T. (2011). Occasional White Boarding: Examining The Effects On Physics Students' understanding Of Motion Graphs. (Unpublished Master's thesis, University of Michigan] [Available at http://services.lib.mtu.edu/etd/THESIS/2011/Education/schwaller/report.pdf [Accessed 6 ${ }^{\text {th }}$ February 2015]

Shavinina, L. V. (2004). Explaining high abilities of Nobel laureates. High Ability Studies, 15(2), 243-254.

Sherin, B. (2006). Common sense clarified: The role of intuitive knowledge in physics problem solving. Journal of Research in Science Teaching, 43(6), 535-555.

Shive, J.N., \& Weber, R. L. (1982). Similarities in physics. Bristol: Adam Hilger Ltd.

Shtulman, A., \& Valcarcel, J. (2012). Scientific knowledge suppresses but does not supplant earlier intuitions. Cognition, 124(2), 209-215. 
Shulman, L. S. (1986). Those who understand: Knowledge growth in teaching. Educational researcher, 15(2) 4-14.

Siegler R. S., \& Crowley K. (1991). The microgenetic method: a direct means for studying cognitive development. American Psychologist, 46(6), 606-620.

Simon, H. A. (1986). The information processing explanation of Gestalt phenomena. Computers in Human Behavior, 2(4), 241-255.

Simon, D. P., \& Simon, H. A. (1978). Individual differences in solving physics problems. In R. S. Sigler (Ed.), Children's thinking: What develops? (pp. 325-348). Hillsdale, NJ: Lawrence Erlbaum.

Sinclair, M. (2010). Misconceptions about intuition. Psychological Inquiry, 21(4), 378386.

Sinclair, M. (Ed.) (2011). Handbook of intuition research. Cheltenham: Edward Elgar Publishing Ltd.

Sinclair, M. (Ed.) (2014). Handbook of research methods on intuition. Cheltenham: Edward Elgar Publishing Ltd.

Sinclair, M., \& Ashkanasy, N. M. (2005). Intuition Myth or a Decision-making Tool? Management Learning, 36(3), 353-370.

Singh, C. (2002). When physical intuition fails. American Journal of Physics, 70(11), 1103-1109.

Singh, V. (2011). Using NASA Science News Articles to Enhance Learning in the Classroom. The Physics Teacher, 49(8), 482-483.

Sio, U. \& Ormerod, T.C. (2009). Does incubation enhance problem solving? A metaanalytic review. Psychological Bulletin, 135(1), 94-120.

Slatkin, M. (1974). Competition and regional coexistence. Ecology, 55(1), 128-134.

Smith, S.M. (1995). Getting into and out of mental ruts: a theory of fixation, incubation, and insight. In R. J. Sternberg \& J. E. Davidson (Eds.), The nature of insight (pp. 229-251). Cambridge, MA: MIT Press.

Smith, E. A. (2001). The role of tacit and explicit knowledge in the workplace. Journal of Knowledge Management, 5(4), 311-321.

Songer, N. B., \& Linn, M. C. (1991). How do students' views of science influence knowledge integration? Journal of Research in Science Teaching, 28(9), 761-784.

Stahl, S. A. (1999). Different strokes for different folks? A critique of learning styles. American Educator, 23(3), 27-31.

Stavy, R., Babai, R., Tsamir, P., Tirosh, D., Lin, F. L., \& McRobbie, C. (2006). Are Intuitive Rules Universal? International Journal of Science and Mathematics Education, 4(3), 417436. 
Sternberg, R.J. \& Davidson, J.E. (1983). Insight in the gifted. Educational Psychologist 18(1), 51-57.

Sternberg, R.J. \& Davidson, J.E. (1995). Preface In R.J. Sternberg \& J.E. Davidson, The nature of insight (pp. xv-xviii). Cambridge, MA: The MIT Press.

Strike, K., \& Posner, G. J. (1992). A revisionist theory of conceptual change. In R. A. Duschl \& R.J. Hamilton (Eds.), Philosophy of science, cognitive psychology, and educational theory and practice (pp. 147-176). Albany, NY: State University of New York Press.

Swaak, J., \& Jong, T. (1996). Measuring intuitive knowledge in science: The development of the" What-IF" test. Studies in Educational Evaluation, 22(4), 341-362.

Taber, K. S. (2001). The mismatch between assumed prior knowledge and the learner's conceptions: a typology of learning impediments. Educational Studies, 27(2), 159-171.

Taber, K. S. (2003). Mediating mental models of metals: Acknowledging the priority of the learner's prior learning. Science Education, 87(5), 732-758.

Taber, K. S. (2004). Intuitive physics: but whose intuition are we talking about? Physics Education, 39(2), 123-124.

Taber, K. S. (2009). Progressing science education: constructing the scientific research programme into the contingent nature of learning science. Dordrecht: Springer.

Taber, K. S. (2013). Modelling learners and learning in science education: Developing representations of concepts, conceptual structure and conceptual change to inform teaching and research. Dordecht: Springer.

Taber, K. S. (2014). The significance of implicit knowledge for learning and teaching chemistry. Chemistry Education Research and Practice, 15, 447-461.

Tallant, J. (2013). Intuitions in physics. Synthese, 190(15), 2959-2980.

Thorsland, M.N. \& Novak, J.D. (1974). The identification and significance of intuitive and analytic problem solving approaches among college physics students. Science Education, 58(2), 245-265.

Treagust, D., \& Duit, R. (2009). Multiple Perspectives of Conceptual Change in Science and the Challenges Ahead. Journal of Science and Mathematics Education in Southeast Asia, 32(2), 89-104.

Tirosh, D., Stavy, R., \& Cohen, S. (1998). Cognitive conflict and intuitive rules. International Journal of Science Education, 20(10), 1257-1269.

Tsai, C. C. (1998). An analysis of scientific epistemological beliefs and learning orientations of Taiwanese eighth graders. Science Education, 82(4), 473-489.

Tyson, L. M., Venville, G. J., Harrison, A. G., \& Treagust, D. F. (1997). A multidimensional framework for interpreting conceptual change events in the classroom. Science Education, 81(4), 387-404.

Von Hofsten, C. (1983). Catching skills in infancy. Journal of Experimental Psychology: Human Perception and Performance 9(1), 75-85. 
Von Hofsten, C., \& Rosander, K. (1996). The development of gaze control and predictive tracking in young infants. Vision Research, 36(1), 81-96.

Von Hofsten, C., Vishton, P., Spelke, E. S., Feng, Q., \& Rosander, K. (1998). Predictive action in infancy: tracking and reaching for moving objects. Cognition, 67(3), 255-285.

Vosniadou, S. (2008). Conceptual Change Research: An Introduction. In S. Vosniadou (Ed.), International Handbook of Research on Conceptual change (1 ${ }^{\text {st }}$ Edition) (pp. xiiixxviii). New York: Routledge.

Vosniadou, S. (2013). Conceptual Change Research: An Introduction. In S. Vosniadou (Ed.), International Handbook of Research on Conceptual change (2nd Edition) (pp. 1-7). New York: Routledge.

Vosniadou, S., \& Ioannides, C. (1998). From conceptual development to science education: A psychological point of view. International Journal of Science Education, 20(10), 1213-1230.

Wagner, R. K., \& Sternberg, R. J. (1985). Practical intelligence in real-world pursuits: the role of tacit knowledge. Journal of Personality and Social Psychology, 49(2), 436-458.

Wagner, U., Gais, S., Haider, H., Verleger, R., \& Born, J. (2004). Sleep inspires insight. Nature, 427, 352-355.

Walker, J. (2008). The flying circus of physics with answers. New York, NY: John Wiley \& Sons.

Wankat, P. C., \& Oreovicz, F. S. (1993). Teaching engineering. New York, NY: McGraw-Hill.

Watson J. D. (1980). The Double Helix: A Personal Account of the Discovery of the Structure of DNA. New York, NY: Norton.

Watts, M. \& Taber, K. S. (1996). An explanatory gestalt of essence: students' conceptions of the 'natural' in physical phenomena. International Journal of Science Education, 18(8), 939-954.

Weisberg, R. W. (1995). Prolegomena to theories of insight in problem solving: A taxonomy of problems. In R. J. Sternberg \& J. E. Davidson (Eds.), The nature of insight (pp. 157-196). Cambridge, MA: MIT Press.

Wellington, J. \& Osborne, J.F. (2001). Language and Literacy in Science Education. Buckingham, UK: Open University Press.

Wertheim, M. (2011). Physics on the Fringe: Smoke Rings, Circlons, and Alternative Theories of Everything. New York, NY: Walker Publishing Company.

West, L. H. T. (1982). The researchers and their work. In: C. Sutton and L. West (Eds.), Investigating children's existing ideas about science. Leicester: University of Leicester, School of Education.

West, L.H.T., Fensham, P.J. \& Garrad, J.E. (1985). Describing the Cognitive Structure of Learners, in: L. H. T. West \& L. H. Pines (Eds.), Cognitive Structure and Conceptual Change (pp. 29-49). London: Academic Press. 
Wiser, M., \& Amin, T. (2001). "Is heat hot?" Inducing conceptual change by integrating everyday and scientific perspectives on thermal phenomena. Learning and Instruction, 11(4), 331-355.

Wolpert, L. (1992). The Unnatural Nature of Science. London: Faber and Faber.

Wren, J. D., Bekeredjian, R., Stewart, J. A., Shohet, R. V., \& Garner, H. R. (2004).

Knowledge discovery by automated identification and ranking of implicit relationships. Bioinformatics, 20(3), 389-398.

Wyatt, J. C. (2001). Management of explicit and tacit knowledge. Journal of the Royal Society of Medicine, 94(1), 6-9.

Ylikoski, P. (2009). The Illusion of Depth of Understanding in Science. In H. De Regt, S. Leonelli \& K. Eigner (Eds.), Scientific Understanding: Philosophical Perspectives (pp. 100119). Pittsburgh, PA: Pittsburgh University Press.

Yukawa, H. (1973). Creativity and Intuition: A Physicist Looks at East and West. Tokyo: Kadansha International Ltd.

Zietsman, A., \& Clement, J. (1997). The role of extreme case reasoning in instruction for conceptual change. The Journal of the Learning Sciences, 6(1), 61-89. 